日薬理誌 $63,572 \sim 592 （ 1967 ）$

\title{
肝障害物質 Ethionine に関する薬理学的研究
}

第 2 篇 Ethionine の朋の機能と形態におよぼす影響

\author{
笠 原 多 嘉 子 \\ (菄京医科大学薬理学教室 [主任 原三郎教援]) \\ (昭和42年 9 月30日受付[特])
}

\section{I 緒言}

数年来，著者らの教室に括いては，原教授扰よびその協同作業者により，肝臓薬理に関する研究が行なるれ

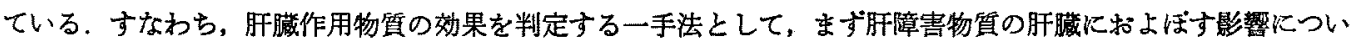
て挨索し，その一定量によって薏起する肝障查を肝疾患の一模型病像としてとりあげ、これに対する薬物の効果 を検討することにより，いわゆる肝贜用薬の效果判定の基準設定を企图してそれに関する実験的検索が行なわれ ている.

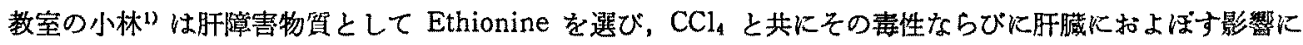
ついて機能，形態の雨面より㛟索した結果，Ethionine の $100 \mathrm{mg} / \mathrm{kg} 3$ 日間皮下交付によって惹起するウサギ 肝障害は，一定度の再現可能な模型病像として適当であると認め，障害成立怄期より回復迄の過程についての観 察結果を報告している.

著者は第 1 篇 $^{2}$ に打いて肝藏薬理研究の一助とするため, Ethionine に関する内外の文献より，特江肝臟作 用を中心として抄読し，作用を系統的に分類して，薬理学的観点よりの考察を加えた．本篇に和いては Ethionine

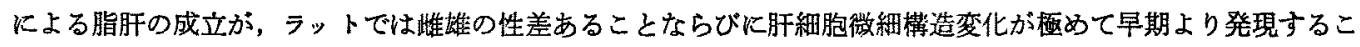
之に着目し，同様の結果がウサギにおいてるみられるか否かを，性差については蛋白，脂質代謝の面から観察 し，障害発現初期より極期に至る間の超薄切片法による微細構造の観察と共に, 細胞レベルに括ける肝の代謝, すなわち肝細胞 Microsome 分画のてミノ酸構成の変化, Negative staining による Mitochondria の形態観

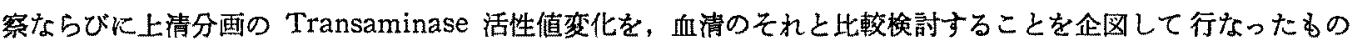
である.

解って，Ethionine は1938年に合成されて以来，Methionine との構造の関連性ならびに生理作用の拮抗性 について，数多くの研究発表があり，特にラットについての報告が多い．また生化学的検索による多くの知見む 得られ，特に ATP レベルよりする代謝面からの解明は注目に值する。しかしながら，Ethionineを薬理学的立 場に立って，その主たる作用部位である肝の機能と形態闭面より作用機構を論した報告は少ない，

生命の基本的粠成単位をなす細胞と，その一定の分化と結合とによって形成される組織，器官についての研 究は，電子顕微鏡の有効な応用により，次々と新しい微細構造の意義が明らかにされるにつれ，目覚ましい勢い で進展しつつある．分子レべルよりする瞥造と機能つ関連こそ，今後の生命現象解析には必須の条件であり， Ethionine の作用機序の解明むまたこの観点よりなさるべきであると信ずる．著者はかかる見解のると火肝疾患 模型病像の実態を把握すべく，前述した項目について実験を行ない，障害成立初期より極期沉至る間の機能と形 態の相関について検討した結果一定の知見を得たのでここに報告する.

\section{II 実験材料ならびに実験方法}

\section{1. 実験材料}

使用薬物は DL-Ethionine (Nutritional Biochemicals Corporation U. S. A.)を $2 \%$ 水溶液として用いた。 実験動物は体重 2.5 3kg の雌雄成熟ウサギを用い，予め一定期間固型飼料（オリエンタル醉母製， RC-5）を もって飼育した後実験に供した. 


\section{2. 実教方法}

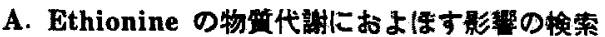

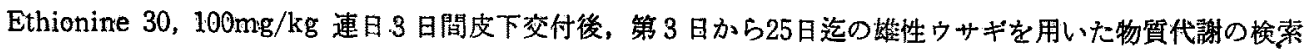
はすでに教室の小林りにより報告されている。ラットにおいて脂肝の成立に著しい性差,すなわち雌に脂肝が生 ビやすいことの報告3,4,5) やそれに対する否定的報告6,7,8,9) があり，ウサギにおいては嶉性 Gray chinchilla が

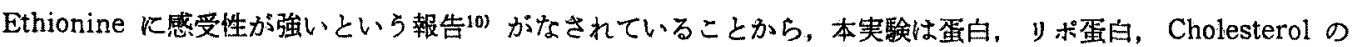
梌索は雌婎両性を用い，また，Ethionine $30,100 \mathrm{mg} / \mathrm{kg}$ 連日 3 日間皮下交付後 1，3，7日について梌索した。

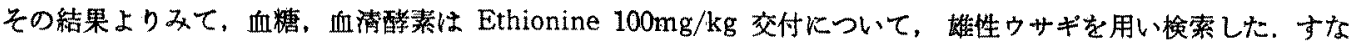

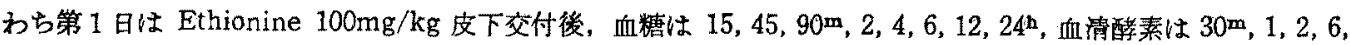
$12 ， 24^{\mathrm{h}}$ ，第 2 日および第 3 日はそれぞれ $100 \mathrm{mg} / \mathrm{kg}$ 交付後 $24^{\mathrm{h}}$ ，すなわち $48 ， 72^{\mathrm{h}}$ 飞採血した．以後 $90 ， 60$ ， $120^{\mathrm{h}}$ 迄について，Ethionine 交付による早期の代謝变化を检索した，な括実験に先立ら予め $12^{\mathrm{h}}$ 絶食 し，採血 は耳静脈から行なった。

1) 蛋白代謝についての実験

血清蛋白量は日立屈折蛋白計を用い，屈折法により蛋白濃度（g/dl）を求めた，血清蛋白分画は沪絓電気泳 動法"1火より測定を行なった。すなわち，小林式汇紙電気泳動装置を使用し，泳動条件として緩衝夜は $\mathrm{pH} 8.6$, イオン強度 0.05 の Veronal 縟㣫液, 沪絓は東洋沪紙 No. 51 を用い, 電流は汇紙巾 $1 \mathrm{~cm}$ 当り $0.6 \mathrm{~mA}$ 通䉓 し, 試料血清 $0.005 \mathrm{ml}$ を原点飞塗布, 原点上り約 $7 \mathrm{~cm}$ 泳動させ乾燥後, $0.2 \%$ Amido black $10 \mathrm{~B}$ 飞て染色 乙, densitometry K上り各分画比を算出した。

2）脂質代謝についての実験

血清リポ蛋白分画は，蛋白分画の測定と同様，沪紙電気泳動法により，試料血清 $0.04 \mathrm{~m} 1$ を泳動後 Sudan black B を用いて染色し， densitometry により分画比を算出した。血清総 Cholesterol は Kiliani 反応に上 る $Z a k$ 氏抽出法の变法 ${ }^{21}$ により処置した後, 分光光電光度計により測定した。

3）糖質代謝についての実験

血糖量の測定を行なった，Somogyi-Nelson 法 ${ }^{13)}$ とより処置後，分光光電光度計を使用して測定した

4）䤑素活性についての実験

血清 Alkaline phosphatase (以下 AL-P) は Kind-King 法(4) に上り測定した. 血清 Transaminase は Reitman-Frankel 法 ${ }^{15)}$ Kより, Glutamic oxalacetic transaminase (以下 GOT), Glutamic pyruvic transaminase (以下 GPT) を測定した.

\section{B. Ethionine の肝細胞分画におよはす影装の模索}

倠婎两性ウサギを用い，Ethionine $30,100 \mathrm{mg} / \mathrm{kg}$ 連日 3 日間皮下交付し，交付終了後第 $1 ， 3 ， 7$ 日にお いて肝標本を採取し実験を行なった．な战予め $12^{\mathrm{h}}$ 絶食の後行ない，全過程 $5^{\circ} \mathrm{C}$ 以下で操作した。 ウサギの顕 椎を外力に上り率引し，脱目させて後直ち開腹し，まず水冷 $0.9 \% \mathrm{NaCl}$ 液 $500 \mathrm{~m} 1$, 次いで氷冷 $0.25 \mathrm{M}$

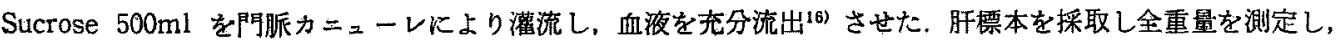
次いで一定量をとり，結合組織を除き細切し，0.25M Sucrose を用い，テフロン軸頭の Potter Elvehjem homogenizer Kて 10\% homogenate 作成した，これを $700 \times \mathrm{g}, 10 \mathrm{~m}$ 遠心し，細胞核，末破液細胞断片等を除去 乙，上清を超遠心分崔法により分画した．日立分離用超遠心嘰 55-P-2 型（RP 40A rotor）を用い，10,000×g， 30m の沈渣を Mitochondria 分画とし，この上清を再び $57,000 \times \mathrm{g}, 60^{\mathrm{m}}$ 高速遠心し, 沈湐を Microsome 分 画，上清を上清分画とした。 な扰 Mitochondria 分画, Microsome 分画は $\mathrm{O}_{8} \mathrm{O}_{4}$ 固定を行ない電子顕徽鏿によ り成分構成を確認した。

1) 肝 Microsome 分画汇ついての実験

Microsome 分画は半透明赤色沈渣として得られるが， 0.25M Sucrose で洗沙後直ちに，真空涷結乾橾機 （共和式 CL-100型）により涷結乾燥品とした。

a. アミ, 酸構成 
肝 Microsome 乾燥品のフミノ酸分析を行ならため, まず Total N 量を Kjeldahl-Nessler 法 $^{(7)}$ により測 定した。 アミノ酸分析用試料は Total $\mathrm{N}$ 量として $0.2 \mathrm{mgN} / \mathrm{ml}$ を $5 \sim 10 \mathrm{ml}$ 使用する.

Microsome 乾燥品を半硬質フンプル中に科量 L, 再留した定沸点 $\mathrm{HCl}$ (b.p. $110^{\circ} \mathrm{C}, 20.3 \%$ ，約 $6 \mathrm{~N}$ ) の20倍

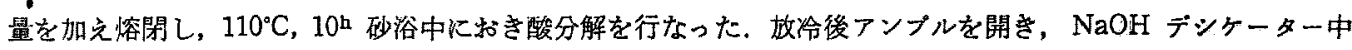

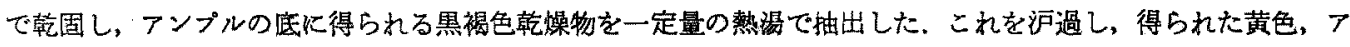

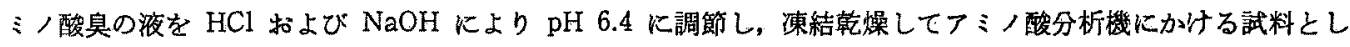

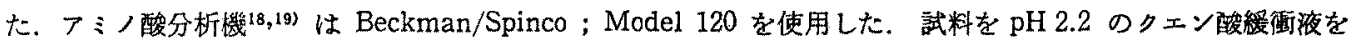
用い Total $\mathrm{N}$ 量を $0.2 \mathrm{mgN} / \mathrm{ml}, 5 \sim 10 \mathrm{ml}$ に調製し，等量宛イオン交换樹脂塔の long column 杖よび short column 飞注入し, $\mathrm{N}_{2}$ ガスで圧入した。最初に short column そ执いて塩基性つミノ酸が溶出, 比色され, 次 いで long column に批いて中性, 酸性つミノ酸が溶出, 比色され, その optical density が連続的に自記され た chartから各フミノ酸量を計算した。な測定結果は18種のアミノ酸, Lysine, Histidine, Arginine， Tryptophan, Aspartic acid, Threonine, Serine, Glutamic acid, Proline, Glycine, Alanine, Cystine, Valine, Methionine, Isoleucine, Leucine, Tyrosine, Phenylalanine を基湖として用い，試料中の百分率で 表現した。 アミノ酸の略号は最初の3文字で示した.

b、微生物定量法による Ethionine の証明

各種つミノ酸 $0.5 \mu \mathrm{M}$ 基海液 (Proline, Ethionine は $1 \mu \mathrm{M}$ ) をてミノ酸分析機にかけると Leucine と Ethionine か゚ 1 つの peak に重なって現かれ，フミノ酸分析の結果だけでは Ethionine 量を定量し得ないため, Leucine の微生物定量 ${ }^{20)}$ を行なった。すなわち，Lactobacillus arabinosus を定量菌株とし，Leucine を除い た完全合成培地を基碟培地とし，これに Leucine の基準溶液を数段階添加接種すると，添加 Leucine 量に応 じて菌株の生育がみられ、これから標準曲線を作成した.フミノ酸分析機にかけたるのと同一試料を基礎培地に 添加後、菌株を接種し，その生育状態から試料中の Leucine 量を求めた、アミノ酸分析による Leucine 量か ら.この Bioassay による Leucine 量を差し引き，Ethionine と Leucine の分子量比でわけ，Ethionine 量 とした.

2) 肝上清分画についての実験

血清 GOT, GPT の挨索と比較検討するため，咯性ウサギを用い，Ethionine $100 \mathrm{mg} / \mathrm{kg}$ 連日 3 日皮下交 付し，第 1 日は $1,2 ， 6 ， 12 ， 24^{\mathrm{h}}$ ，第 2 、第 3 日はそれぞれ $100 \mathrm{mg} / \mathrm{kg}$ 交付啳 $24^{\mathrm{h}}$ ，すなわち $48 ， 72^{\mathrm{h}}$ にわたり 梌索した．肝細胞分画法により採取した超遠心上清分画について，GOT，GPT 活性を Reitman-Frankel ${ }^{13)}$ 法に より泪定した，上清分画はリン酸緩衝液で $\mathrm{pH} 7.4$ に調整した生理食塩水により，50倍稀釈したものを血清の場 合と同様の操作により測定を行なった。

\section{Ethionine の肝微絧構造におよはす影辢の模索}

1) 超薄切片法に上る微細構造の観察

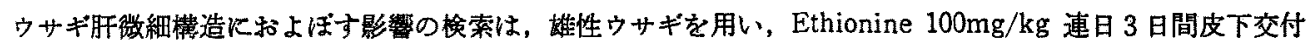
し, 第 1 日㤌 $30^{\mathrm{m}} 1 ， 2 ， 6 ， 12 ， 24^{\mathrm{h}}$ ，第 2 ，第 3 日忙それぞれ $100 \mathrm{mg} / \mathrm{kg}$ 交付後 $24^{\mathrm{h}}$ すなわち $48,72^{\mathrm{h}}$ の各

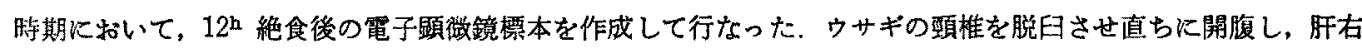
葉から拇指頭大の肝切片を採取し， $4^{\circ} \mathrm{C}$ 以下の条件で Glutaraldehyde 固定および $\mathrm{O}_{8} \mathrm{O}_{4}$ 再固定を行なった.

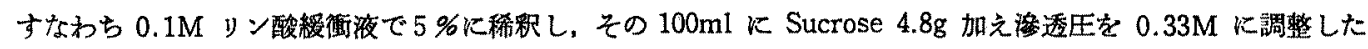
Glutaraldehyde 固定液を揾指頭大の肝切片の10３0倍量用い，約 40 m 固定した後，14\% Glucose に移し米室

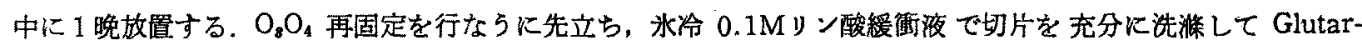
aldehyde を完全に除去する．これをParaffin wax 板上に置き， $\mathrm{O}_{8} \mathrm{O}_{4}$ 固定液である Milloning 改良法固定液

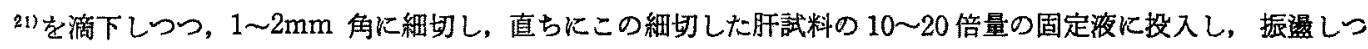
つ約 $1^{\mathrm{h}} \mathrm{O}_{8} \mathrm{O}_{4}$ 固定を行なった. 脱水は水冷しておいた Ethanol, Acetone 系列を用い室温で行なった. 30,50, 70, 80\% Ethanol 飞各 10 20m, 90\% Ethanol k $\overline{3}^{\mathrm{m}}, 90 \%$ Ethanol-Acetone $(1: 1) k 5^{\mathrm{m}}, 90 \%$ Acetone K 5m, 100\% Acetone K 10 15m, Absolute Acetone K 5m と脱水し，各回毎に 2 3 回液を交換する. 包 
埋は22) Epoxy 系樹脂, Epon 812, 硬化剤 DDSA (Dodecenyl succinic anhydride), MNA (Methyl nadic anhydride) および冓合加速凨 DMP-30 (2, 4, 6-Tri [dimethyl aminomethyl] phenol) を用いた. Epon 812 にDDSA を加えたA液と MNA を加光たB液とを実験時期の気温に適した混合比により混合した mixture は 充分摫䢁後堿压してガスを抜いて扣く，脱水した肝切片試料は Absolute Acetone-Epon mixture (1:1) に 移し，室温で約 $3^{\text {h }}$ 置さ，次いで Epon mixture のみで 1 晚室温に放圈する. 翌日新しいEpon mixture と

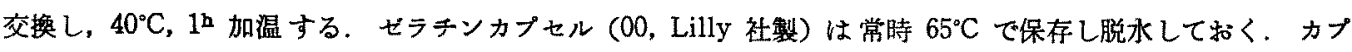
セルに試料名を記入した綎を入れ，新しいEpon mixture を满たし，肝試料を1個ずつ入れ自然に沈降させ，

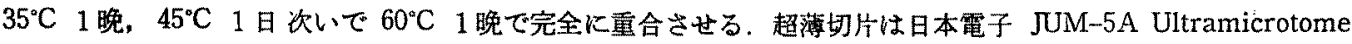
にて作成し, 日本電子製顕微鏡 JEM-7 とより観察を行なった。

2) Negative 染色法による微細構造の観察

超薄切片法と同時期に拈ける Mitochondria 分画について, リンタンダステン酸法により Negative 染色 ${ }^{23)}$

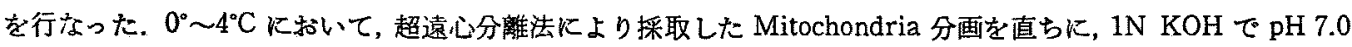
とした $2 \%$ リンタングステン酸と混合し，それをCollogione 膜を張り, Carbon 蒸着した 15 mesh の seat

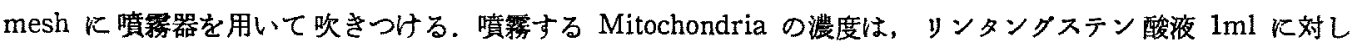
1〜3mg 程度である. 嗔簙した seat mesh は低温で保存し，なるべく速やかに電子頭徽鏡で観察した。

\section{III 実 験 成 績}

\section{A Ethionine の物而代謝におよはす影礐の梌索}

1）㔻白代謝についての実験

本実験に淤けるウサギ血清総蛋白量正常値は，雄が $6.1 〜 6.4 \mathrm{~g} / \mathrm{dl}$, 此が $5.6 \sim 5.7 \mathrm{~g} / \mathrm{dl}$ であった. Ethionine $30 \mathrm{mg} / \mathrm{kg}$ 連日 3 日間皮下交付後 $1 ， 3 ， 7$ 日の変化は，雄では $6.0,5.7,6.0 \mathrm{~g} / \mathrm{dl}$ とやや減少後回復し，雌で は $6.1,6.0,5.4 \mathrm{~g} / \mathrm{d} 1$ と増加後回復した. $100 \mathrm{mg} / \mathrm{kg}$ 連日 3 日間皮下交付後 $1 ， 3 ， 7$ 日の変化は，雄では 5.8 , $5.5,5.9 \mathrm{~g} / \mathrm{d} 1$ と減少後回復し, 雌では $6.1,5.8,5.7 \mathrm{~g} / \mathrm{dl}$ と増加後回復している.

本実験に拊けるウサギ血清蛋白分画正常值は，雄に㨟いては Albumin 3.0 3.3g/dl, $\alpha$-Globulin $1.1 \mathrm{~g} / \mathrm{dl}$, $\beta$-Globulin 0.9 1.0g/dl, $\gamma$-Globulin 1.1g/dl であり, 崔では Albumin $2.8 \sim 2.9 \mathrm{~g} / \mathrm{dl}$, ; $\alpha$-Globulin $1.0 \sim 1.1 \mathrm{~g} / \mathrm{dl}$, $\beta$-Globulin $0.8 \sim 0.9 \mathrm{~g} / \mathrm{dl}, \gamma$-Globulin $0.9 \sim 1.0 \mathrm{~g} / \mathrm{dl}$ であつた. Ethionine $30 \mathrm{mg} / \mathrm{kg}$ 連日 3 日間皮下交付後の変 化は、溚では Albumin が第 1 日に $0.7 \mathrm{~g} / \mathrm{dl}$, 第 3 日に $0.9 \mathrm{~g} / \mathrm{dl}$ と隇少し， $\alpha$-Globulin は第 1 日に $0.3 \mathrm{~g} / \mathrm{dl}$ 減 少し，以後第 7 日で回復傾向を示し， $\beta$-Globulin は第 1 日に $0.3 \mathrm{~g} / \mathrm{dl}$ 增加し，以後それを維持し， $\gamma$-Globulin は第 1 日に $0.4 \mathrm{~g} / \mathrm{dl}$ 增加し，第 7 日でやや回復傾向を示した。雌では Albumin が漸減し，第 7 日で $0.7 \mathrm{~g} / \mathrm{dl} の$ 減少を示し， $\alpha$-Globulin は第 1 日Kやや增加し，以後回復した. $\beta$-Globulin は第 3 日にやや増加し, $\gamma$-Globulin は第 1 日に $0.3 \mathrm{~g} / \mathrm{dl}$ 増加後回復した. $100 \mathrm{mg} / \mathrm{kg}$ 連日 3 日間皮下交付後の変化は, 蜼では Albumin は第 1 日 K $30 \mathrm{mg} / \mathrm{kg}$ 交付の場合と同程度隇少し，第 3 日で $1.5 \mathrm{~g} / \mathrm{dl}$ 減少し，第 7 日で回復した. $\alpha$-Globulin は第 3 日

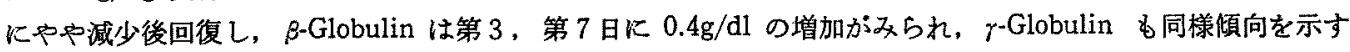

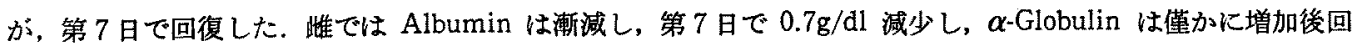
復し， $\beta$-Globulin は第 1 日K $0.3 \mathrm{~g} / \mathrm{dl}$ 增加し, $\gamma$-Globulin は第 1 ， 3 日と $0.6 \sim 0.7 \mathrm{~g} / \mathrm{dl}$ 增加し，第 7 日で回 復傾向を示した，A/G 比柱全例低下゙するが, $100 \mathrm{mg} / \mathrm{kg}$ 交付群の雄の場合が最も著しく, $30 \mathrm{mg} / \mathrm{kg}$ 交付の婎が それ次ぎ, $30 \mathrm{mg} / \mathrm{kg}$ 交付の倠が一番低下が僌度であった（第 1 図）.

Ethionine 飞よる血清蛋白の变化について，交付条件は種々であるが，次の報告がある．Poolら年）は雄性 ラットにおいて, Albumin, $\gamma$-Globulin に著変なく， $\alpha$ - $\beta$-Globulin の減少をみたと報告し，Huttereら ${ }^{25)}$ は

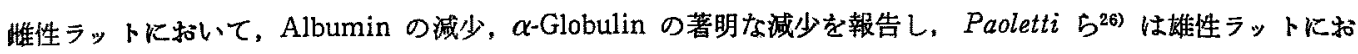
いて， $\alpha$-Globulin の滅少， $\gamma$-Globulin の增加を報告した.Wang ら $\gamma$-Globulin, 特に $\gamma$-Globulin の減少が著しく, $\beta$-Globulin はやや増加すると述べている. 本教室の近藤, 中川路27 （坂本）は雄性ウサギを用い，総蛋白量，Albumin の減少， $\alpha-\beta-, \gamma$-Globulin の增加傾向を認め，小林” 
は婎性ウサギを用い，総蛋白量, Albumin， $\alpha$-Globulin の城少と， $\beta$ - $\gamma$-Globulin の增加を報告し，Wangら

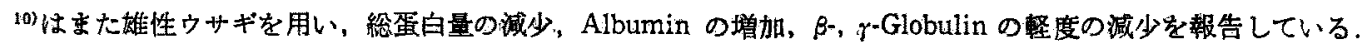

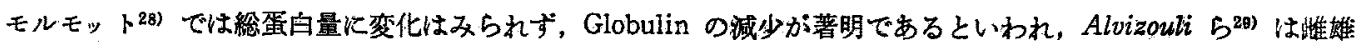

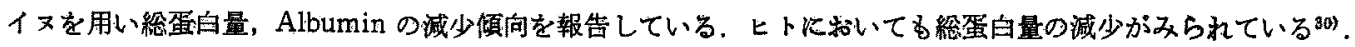

これらの報告は使用動物，交付量，交付期間等条件が異なって括り，直ちに比較は出来ないが，総蛋白量は 変化がないか，娍少するすのが多く，Albumin，Globulin については一致した傾向はみられない，本教室にお ける雄性ウサギについての実験では，総蛋白量. Albumin の減少， $\beta-, \gamma$-Globulin の增加扰よび A/G 比の低 下が一致して秥り， $\alpha$-Globulin については必ずしも一致していない，本実験の倠性ウサギでは一時総蛋白量 が增加した後回復して括り，その他は雄性ウサギの結果にほ汪一致した。

2）脂質代謝についての実験

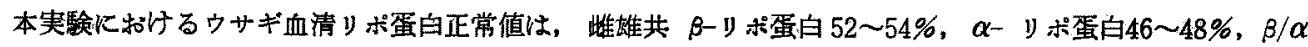

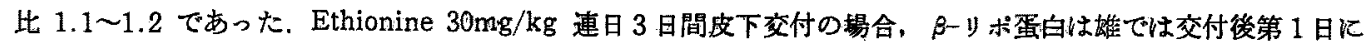
著変なく，第 3 日に $9 \%$ 増加し，第 7 日には回復傾向を認め，雌では第 1 日から增加しはじめ，第 3 日には $28 \%$
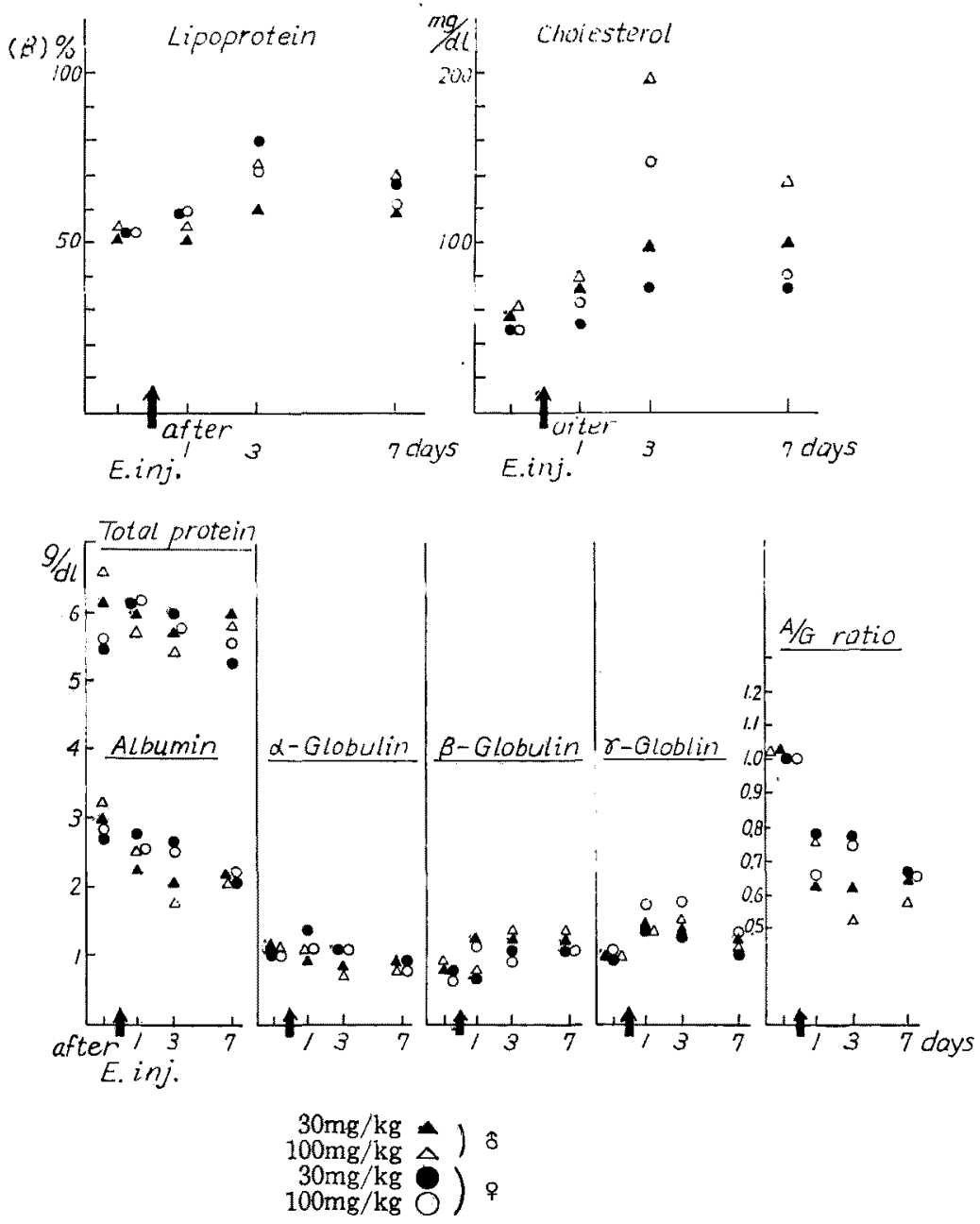

第 1 図. Ethionine 备量連日 3 日間皮下交付による蛋白, 脂質代謝. 
日には回復傾向を認めた。 $100 \mathrm{mg} / \mathrm{kg}$ 連日 3 日間皮下交付の場合，雙雄共第 3 日に $19 \%$ 增加し，第 7 日には回復 㑯向を認めた（第 1 図).

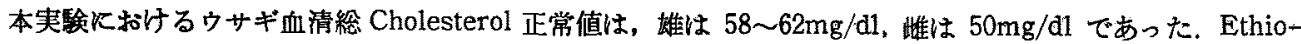
nine $30 \mathrm{mg} / \mathrm{kg}$ 交付の場合, 婎では第 3 日に $100 \mathrm{ml} / \mathrm{dl}$ に上年し，第 7 日においても隇少せず，雌では第 3 日に

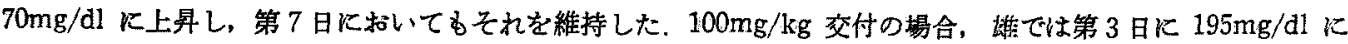
上界し，第 7 日には $100 \mathrm{mg} / \mathrm{dl}$ に下降した。䨀では第 3 日に $145 \mathrm{mg} / \mathrm{dl}$ に上年したが，第 7 日には $80 \mathrm{mg} / \mathrm{dl}$ K下降した，血清総 Cholesterol の增加は Ethionine $100 \mathrm{mg} / \mathrm{kg}$ 交付の場合，第 3 日を極期として雄性ウサギ

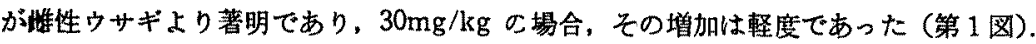

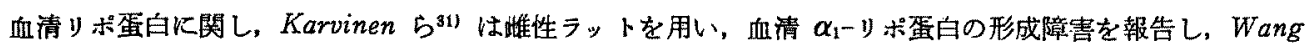

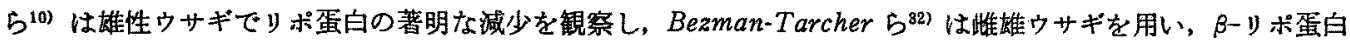

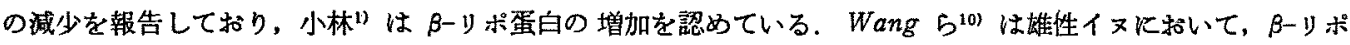

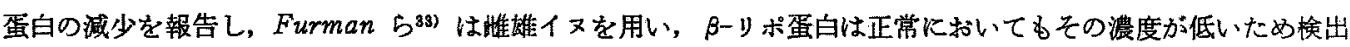

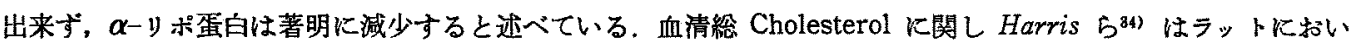

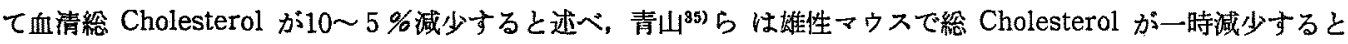
報告している. Feinberg ら ${ }^{36)}$ はイヌを用い, 総 Cholesterol はやや増加後急激に減少すると報告している.

血清脂質 (Ester Cholesterol, Cholesterol, 中性脂肪, 脂肪酸、リン脂貿) ははとんどリポ蛋白に担われ， リポ蛋白はその運搬と pool の役目を果している，この血中濃度は各種脂塤の吸収，合成，分解および眝蔵等の 代謝を反映する一万その減少は蛋白生合成の低下をる反映するが，本実験では低比重で， Ester Cholesterol，

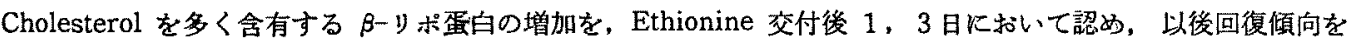
認めた。

以上の蛋白, 脂質代謝の恰索により，ウサギにおいては特に雌が Ethionine に対し常に高い感受性を示す といら結果は得られなかった。

3）榜質代謝についての奏験

本実験に新けるウサギ正常血㜍值は $84 〜 108 \mathrm{mg} / \mathrm{d} 1$ であった. Ethionine $100 \mathrm{mg} / \mathrm{kg}$ 交付直後より軽度の 增加傾向を現わすが，24h でほぼ交付前の值に戻り，96,120h では軽度減少傾向を認めた。これは第10日には ほぼ回復した（第2四）。

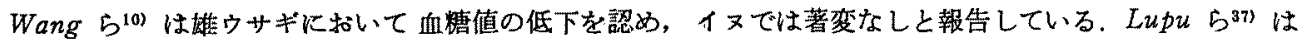

$$
\text { Blood sugar }
$$

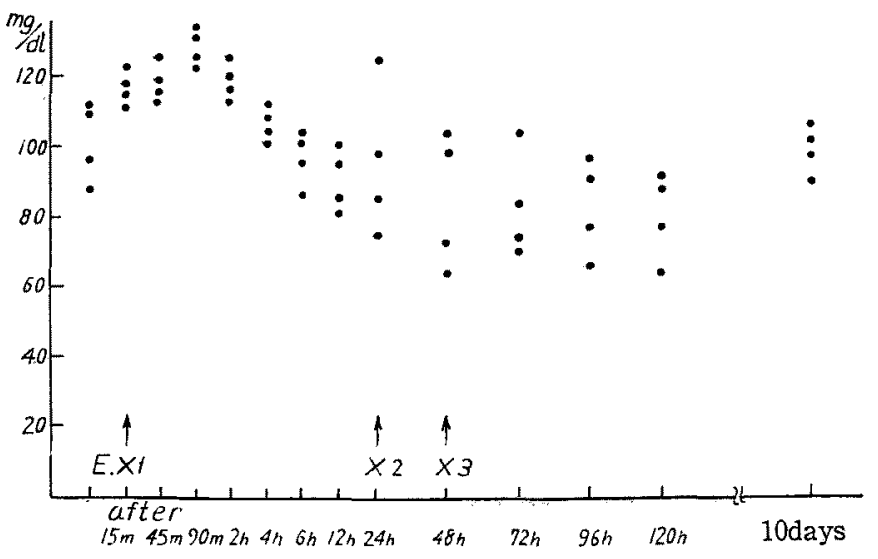

第 2 図. Ethionine $100 \mathrm{mg} / \mathrm{kg}$ 連日 3 日間皮下交付によるウサギ(っ)の血糖. 
ラットに括いて旰 Glycogen 低下作用を報告している，Ethionine は勝の腺房細胞は特異的に障害するが，広 範に障害されない限り Langerhans 島には障管を与古ないといわれる には Glycogen $\rightarrow$ Glucose の過程汇働く Glucose-6-Phosphatase が局在412 し，Ethionine 交付後早期にその

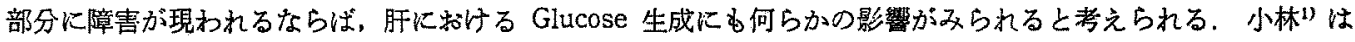
Ethionine 交付により Endoplasmic reticulum の断裂，消失を観察しているが，その時点に Glucose-6-Pho-

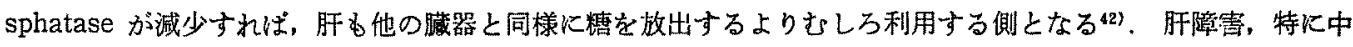
毒性肝炎，急性黄色肝萎縮等では低自糖がみられる．Ethionine 交付による肝 Endoplasmic reticulum の变化

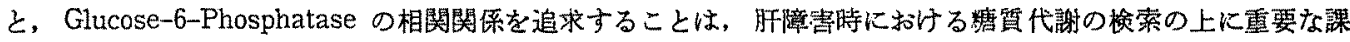
題であると思われ，今後の研究続行を予定している.

4) 醉菜活性についての実験

本実験に括斿るウサギ正常値は，血清 GOT は 10〜50, GPTは 23 40 Karmen 単位(以下 KU) であ

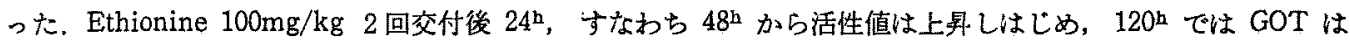

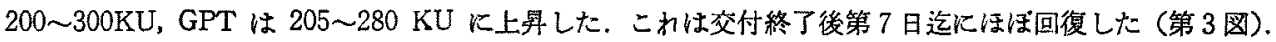

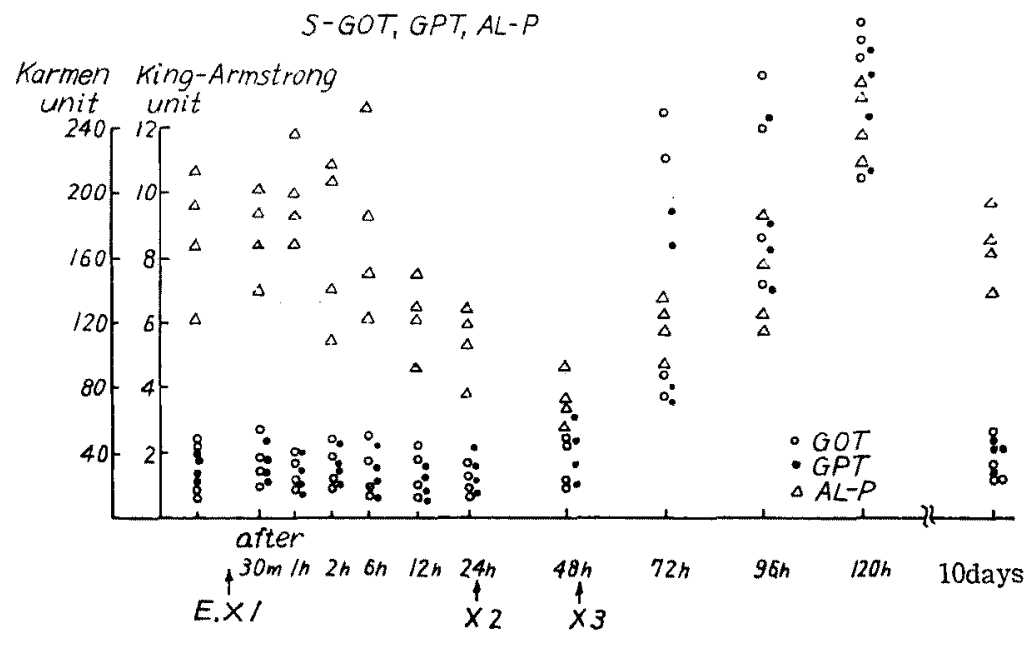

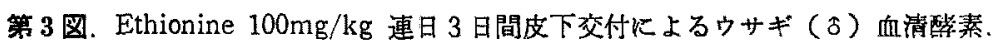

福井ら43) はラットを用い，GOT，GPT の上昇を報告し，古川ら41) は有意の変化をみないと述べている． 小林 ${ }^{1)}$ は本実験と同様の投与方法に执いて，Ethionine $100 \mathrm{mg} / \mathrm{kg}$ 連日 3 日間皮下交付後第 3 日，すなわち $120^{\mathrm{h}} 飞$ GOT，GPT の上昇報告したが，本実験に拗いてこ机は Ethionine 交付後 $72^{\mathrm{h}}$ 頃から，著明に上界 しはじめるものであることを認めた。

本実験における血清 AL-P 正常值は 6〜10.3 King-Armstrong 単位であった. Ethionine $100 \mathrm{mg} / \mathrm{kg}$ 連

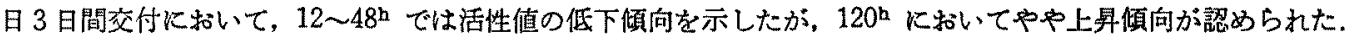
こ礼は交付終了後第 7 日迄注ほほ回復した（第 3 図）.

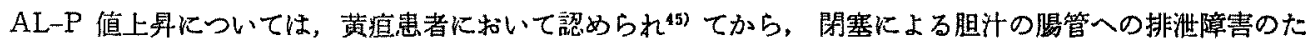
めとも，また停滞した胆汁成分により，肝細胞が刺激され AL-P 産生が過剩になるためとるいわれ，未だ不明 な点が多い，ウサギに蛹いては比較的短期間の Ethionine 交付飞より，胆細管变形がみられている.

\section{B. Ethionine の肝細胞分画におよはす影響の検索}

1) 肝 Microsome についての実験

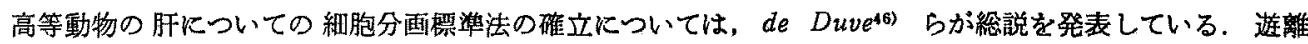


Ribosome Endoplasmic reticulum の小破片を完全に沈測せしめるには，Mitochondria 分画を除いた上清 を $105,000 \times \mathrm{g}, 60^{\mathrm{m}}$ 遠心を行ならが，大部分のすのを集めるには，すっと低い遠心力で充分であるとされ，本 史験は $57,000 \times \mathrm{g}$ 47) で行なった。

a) アミノ酸構成

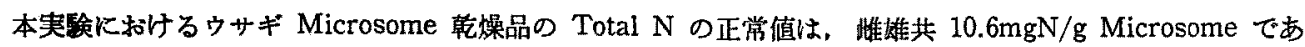
った. Ethionine 30mg/kg 連日 3 日間皮下交付後 1，3，7 日の Total $\mathrm{N}$ 量は Microsome 乾燥品 $1 \mathrm{~g}$ につ き，雄では 11.6，11.8，12mgN であり，倠では $12.2 ， 13.6 ， 10.6 \mathrm{mgN}$ であった. $100 \mathrm{mg} / \mathrm{kg}$ 連日 3 日間皮下交 付後 1，3，7日では，雄は 15，14.1，13.4mgN 倠は 11.9，13.1，10.7mgN であった。

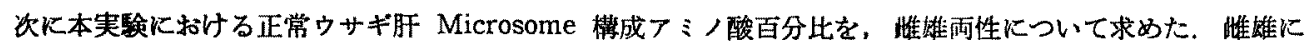
やや差がみられたが，その構成は Glu，Leu が多く，His，Ser, Met, Tyr が少なく，全体の比率はほ济似た傾 向を示した（第 4 図).

Ethionine $30,100 \mathrm{mg} / \mathrm{kg}$ 交付後 1，3，7 日について, 雄では第 1 日飞 Lys, His, Glu の增加, Arg, Leu, Tyr, Phe の隇少がみられ，第 3 日では $30 \mathrm{mg} / \mathrm{kg}$ 交付群に Leu の減少がみられ，第 7 日では Glu, Leu の減少と, $30 \mathrm{mg} / \mathrm{kg}$ 交付群での Met, Tyr の增加が著明である. 雌では第 1 日に括いて Lys, Arg, Asp の 增加, Glu, Val, Ileu, Leu の減少がみられ，第 3 日では $30 \mathrm{mg} / \mathrm{kg}$ 交付群に执いて Lys, Glu, Pro, Val, Phe, Leu の減少, $100 \mathrm{mg} / \mathrm{kg}$ 交付群では Asp, Glu の減少が珰められ，第 7 日では Asp, Tyr が多く, $100 \mathrm{mg} / \mathrm{kg}$ 交付群の Leu がやや減少した（第 5 図).

b) 微生物定量法による Ethionine の証明

アミノ酸分析機による Microsome のてミ/酸構成の梌索においては，その各アミ/酸量の変化と共に， Ethionine または Ethionine 含有異常 Polypeptide の pattern が見出されることを期待していたが，基準つ ミノ酸夜に Ethionine を混合した分析結果により，Ethionine は Leucine 分画に一致し， peak が相加されて 現われた.このため微生物定量法により Leucine 分画中の Leucine 量を求め, アミノ酸分析との差をEthionine 量とすることにした. Ethionine $30,100 \mathrm{mg} / \mathrm{kg}$ 連日 3 日間交付雄性ウサギについて, 交付後 1，3，7日の定 量結果では, $30 \mathrm{mg} / \mathrm{kg}$ 交付では第 3 日に, 定量誤差を差し引いても Ethionine が䄪 $2.3 \mathrm{mg} / 100 \mathrm{mg}$ Microsome, $100 \mathrm{mg} / \mathrm{kg}$ 交付では第 7 日において子約 $1.5 \mathrm{mg} / 100 \mathrm{mg}$ Microsome が存在することが認められた。この Ethionine の交付量と交付後の経過を比較検討すれば，Ethionine は $100 \mathrm{mg} / \mathrm{kg}$ 連日 3 日間皮下交付では交付後第 1 日で認められ，以後 $3 ， 7$ 日と漸城し，30 $\mathrm{mg} / \mathrm{kg}$ 連日 3 日間交付では交付後 3 日で $100 \mathrm{mg} / \mathrm{kg}$ 交付隦と注ぼ同 量の Ethionine の存在が認められ。

第 7 日迄汇消失すると考觉られる（第 6 圆).

Ethionine は蛋白合成を阻害し， Microsome, Ribosome 分画 ${ }^{49}$ への丁 ミノ酸のとりこみを阻止すると共炕, Ethionine それ自身も蛋白中へとりこ

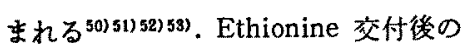
旰微紐構造の変化についても，ラット では早期から rough-Endoplasmic reticulum $の$ Ribosome $の$ 脱落 ${ }^{(4)}$ 中 Poly-ribosome の分散 ${ }^{55)}$, Endoplasmic reticulum の構造変化 ${ }^{58)}$ が観察 されている. Microsome 分画はこれ Бの Ribosome p rough-, SmoothEndoplasmic reticulum 等が径 0.1

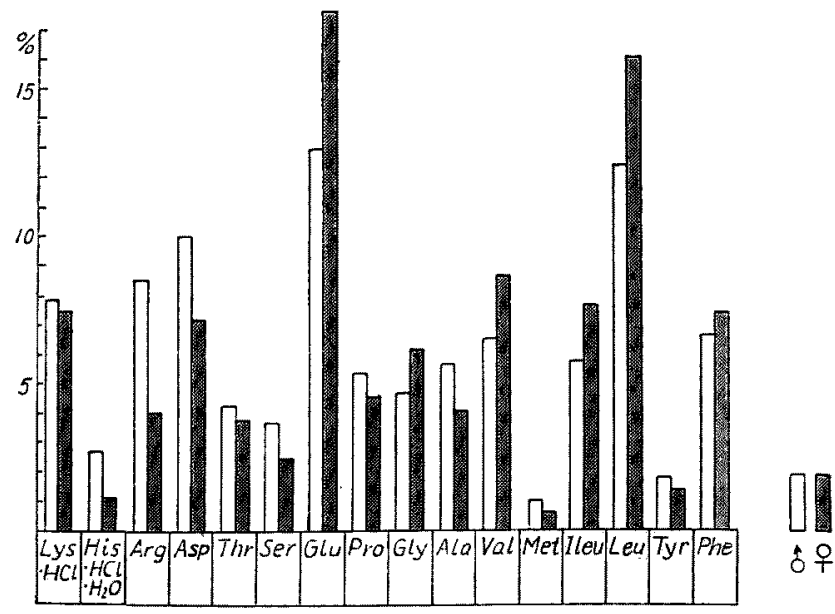

第 4 图. ウサギ（る， ㅇ）正常肝 Microsome 構成蛋白の 了ミ/酸百分比. 

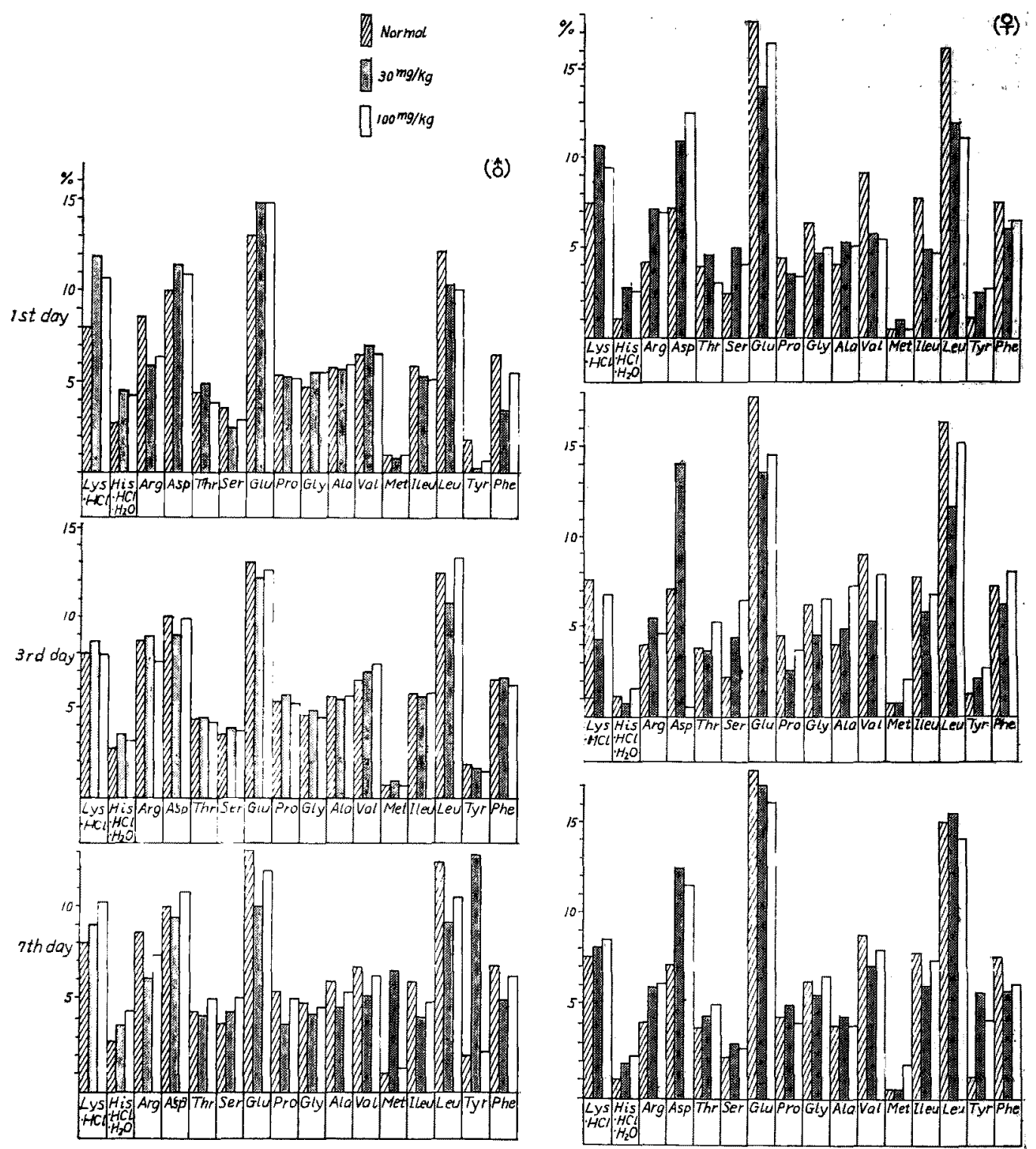

第 5 图. Ethionine $30 \mathrm{mg} / \mathrm{kg}, 100 \mathrm{mg} / \mathrm{kg}$ 連日 3 日間皮下交付によるウサギ（る，q） 肝 Microsome 構成蛋白のアミ/酸百分比.

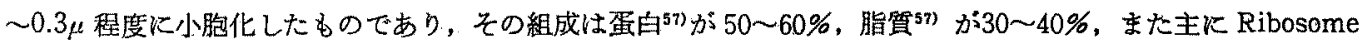
に由来すると教光られている RNA ${ }^{58)}$ も存在する。脂質の50 80\%はリン脂質であり，この60〜90\%が Phosphatidyl-choline (Lecithin), Phosphatidyl-ethanolamine (Cephalin) でこれに次いで Phosphatidyl-serine 6含有され，約20\%は Cholesterol 等である ${ }^{596)}$.

Microsome 分画の蛋白教成についての知見(1) は少なく，全蛋白の10 15\%が Ribosome 蛋白で，夾雑物 等の蛋白す西るが，大部分は Endoplasmic reticulum の膜を楧成している蛋白であろうと推測されている また，Microsome は種々の酵素が存在し，醳素蛋白可成りの部分を占めていると考えられるが，それについ 


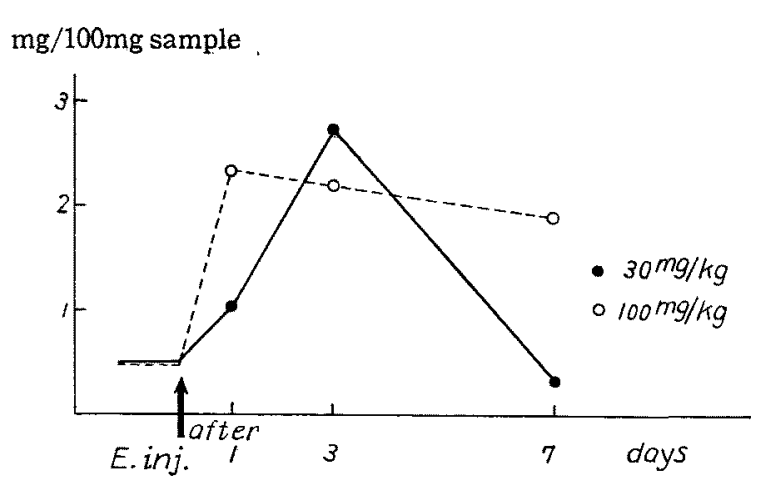

\begin{tabular}{|c|c|c|c|c|c|}
\hline \multicolumn{4}{|c|}{$\begin{array}{c}\mathrm{mg} / 100 \mathrm{mg} \mid \text { Analyer Bioass- } \\
\text { sample (A) } \quad \text { L-ay (B) }\end{array}$} & $(A-B)$ & $\begin{array}{l}\mathrm{Et} / \mathrm{Leu} \times \\
(\mathrm{A}-\mathrm{B}) \\
\text { Ethionine }\end{array}$ \\
\hline \multicolumn{2}{|c|}{ Normal } & 1.97 & 1.62 & 0.35 & 0.44 \\
\hline \multirow{3}{*}{ 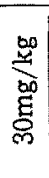 } & $\begin{array}{c}1 \\
1\end{array}$ & 1.72 & 0.92 & 0.80 & 1.00 \\
\hline & 3 & 3.32 & 1.16 & 2.16 & 2.72 \\
\hline & 7 & 1.14 & 0.96 & 0.18 & 0.23 \\
\hline \multirow{3}{*}{ 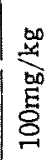 } & 1 & 2.86 & 1.03 & 1.83 & 2.29 \\
\hline & 3 & 2.85 & 1.17 & 1.68 & 2.10 \\
\hline & 7 & 2.72 & 1.15 & 1.57 & 1.95 \\
\hline
\end{tabular}

第6 図. Amino acid analyzer および Bioassay による Leucine 分画中の Ethionine 量.

ての知見はほとんとみられていない，Ribosome 蛋白の大部分は一応構成了ミノ酸とされている(6364)65).

また，Microsome は脂質代謝，ステロイド代謝，酸化還元代謝，電子伝遟系捛よび醉素代謝等に関与し， 投与薬物の代謝、解毒その他肝に特異的な機能を代表する場である. Ethionine 交付による肝の機能と形態の検 索により，Microsome 飞関係ある血清中の諸代謝の变化と Endoplasmic reticulum の形態の变化が観察され ている゙が，その同時期において肝 Microsome 分画の蛋白哖成に，何等かの变化が起こることは充分推測され る. $57,000 \times \mathrm{g}, 60^{\mathrm{m}}$ の高速遠心により採取される Microsome 分画は Endoplasmic reticulum が大部分を占 めてはいるが，均一なものではないとされ沟，より詳細を極めるには smooth-Endoplasmic reticulum, roughEndoplasmic reticulum, Ribosome 等を細分画 ${ }^{67768)}$ して検索を行なうことが望ましいが，本実験はその前段階 として, Microsome 分画全体の検索を行なったるのでる.

㔻白の酸加水分解法69は，アミノ酸の破壊が少ないといわれ，最す一般的な方法である．塩基性アミノ酸は ほとんど分解されないが，熱 $\mathrm{HCl}$ に不安定な Cys, Met, Tyr, Ser, Try, Thr は $6^{\mathrm{h}}$ の加熱で最大分析値と

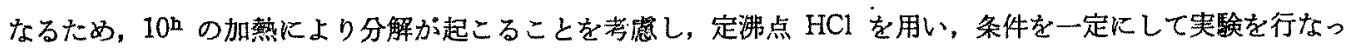
たが, Cys, Try は分解され測定出来なかった. Microsome 分画の Total N 量の測定は，アミノ酸分析機を 用いての检索を行なら上に必要であったため行なったものであるが, 雌雄共 Ethionine 交付後 1 ～ 3 日で增加 を示し，以後㴬次正常に回復している．Total $\mathrm{N}$ 量として定量されるるのは蛋白性 $\mathrm{N}$ および核酸性 Nであるが， この增加を Microsome 蛋白の増量とみれば， Microsome 粠造蛋白の変化か，または Microsome 分画中の Endoplasmic reticulum の量的变化が推測される。電子顕微鏡的観察により，Ethionine $100 \mathrm{mg} / \mathrm{kg}$ 連日 3 日 間皮下交付後 1，3日に rough-Endoplasmic reticulum の減少と相対的に smooth-Endoplasmic reticulum の增加傾向とも考学られる所見がみられるが，これを反映しているとも考劣られる。

箸本 ${ }^{70)}$ はウサギ Microsome 分画について, 正常では, rough-Endoplasmic reticulum が多く, smoothEndoplasmic reticulum は比較的少ないが, Aniline, Acetanilid, Butter yellow 等を 2w 以上投与すると smooth-Endoplasmic reticulum が多くなると述べている. rough, smooth-Endoplasmic reticulum は細胞質 内に 3 次元的な網工を作るといら共通の特徴を有しているが，単なる Ribosome の有無たけではなく，その化 学成分，䤃素活性には可成りの相違があると考えられている. Ethionine 交付により, 肝 Microsome 蛋白の丁 ミ/酸構成に現われた変化については，これ迄ウサキ゚肝 Microsome 蛋白に関する報告が少ないので結果報告に

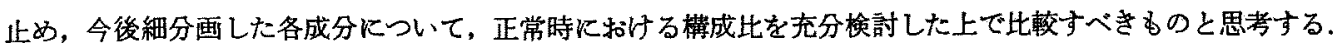

Ethionine のとりこみの証明については, フミノ酸分析による Leucine の pattern より求めた全体量か ら，微生物定量法による Leucine 量を差し引いたものを Ethionine 量としたが，誤差は 0.44mg/100mgsample であり, Ethionine 含有が最大である $30 \mathrm{mg} / \mathrm{kg}$ 交付群の第 3 日の定量值 $2.7 \mathrm{mg} / 100 \mathrm{mgsample}$ と比し明 らかに有意の差を認めた。酸分解や Bioassay の手技を経て,なお肝 Microsome 中に Ethionine が認められ たと結論しらると思考する。 
2）肝上清分画汇ついての実験

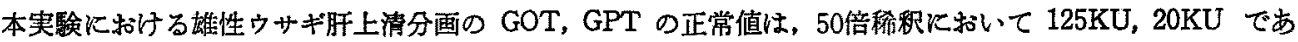
った. GOT については Ethionine $100 \mathrm{mg} / \mathrm{kg}$ 連日 3 日間皮下交付後 $1,2,6,12^{\mathrm{h}}$ 之時間経過につれやや变動

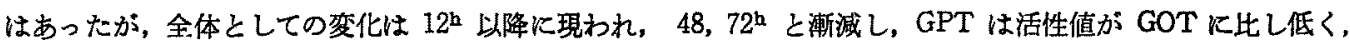
測定值にばらつきがあったが, GOT とほぼ同一傾向を示した(第 7 図).
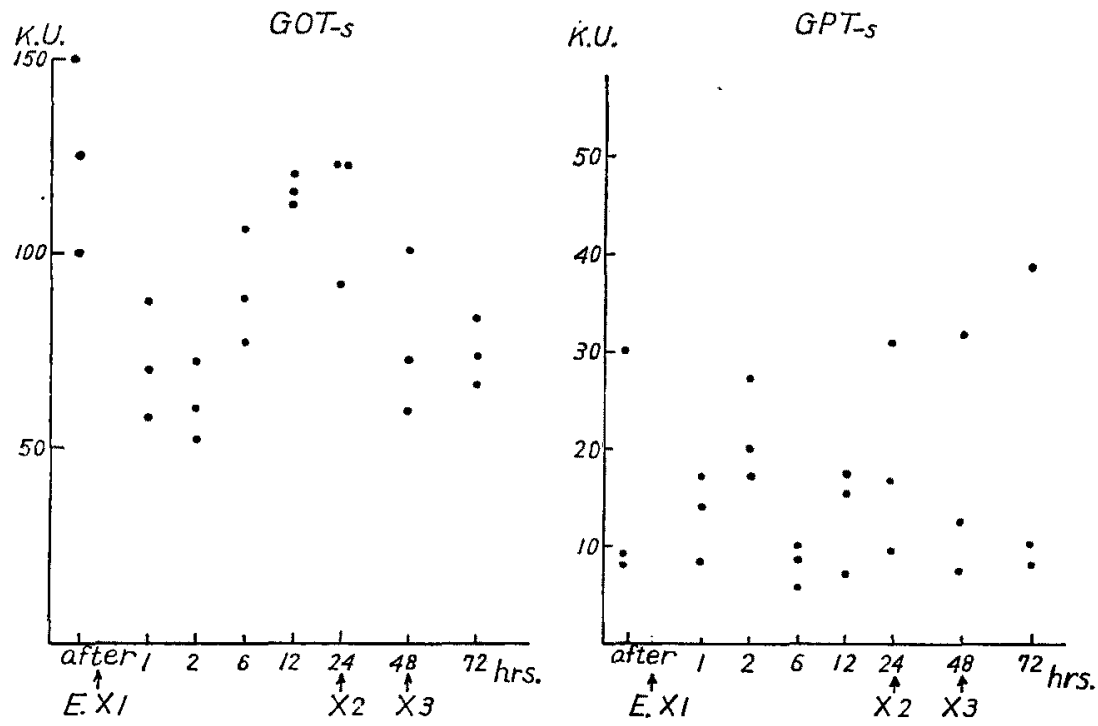

第 7 図. Ethionine $100 \mathrm{mg} / \mathrm{kg}$ 連日 3 日間皮下交付によるウサギ（る）朋細胞上清 分画 GOT, GPT 活珄値.

肝障害時に血清中に GOT, GPT が上昇してくる原因は，肝細胞膜の透過性の変化により血清中へ漏出す ることによるとされている．このことから肝細胞中の Transaminase の低下と血清中のそれの上年は時間的に 相関すると考えられる。 また，七ト肝においては GOT が GPT に比しはるが多く含まれているが，GOT の 方が漏出しにくく分解しやすいため，血清中の GOT，GPT の活性単位は肝飞比し差が小さいといわれる.

Ethionine $100 \mathrm{mg} / \mathrm{kg}$ 連日 3 日間皮下交付時の Transaminase の変動については, 肝飞括いて $12^{\mathrm{b}}$ 以降に みられる GOT 活性值の低下傾向と，血清に新ける $24^{\mathrm{b}}$ 以降の GOT 活性上界は明らかk相関していると考え られる、GPT については，ばらつき認めるが他の実験結果より類推して本質的には相関を示すすのと考えら わる.

Transaminase は肝の Mitochondria 分画, 上清分画飞局在し, Mitochondria 飞局在するすのは, 内部椹 造に密に結合して括り ${ }^{71}$ ，肝障害時に血清中に漏出するのは上清分画のるのとされているため，本実験結果と一 致するが、Ethionine 肝障害時には形態的に Mitochondria 飞る变化がるられることから，血清中に上界する Transaminase の Isozyme 分離定量を行ならことにより，より詳細な障害像が把握出来ると考えられ，今後の 検討課題としている.

C Ethionine の肝微勫粸造におよばす影帮の検索

1）超薄切片法による微細構造の観察

Ethionine $100 \mathrm{mg} / \mathrm{kg}$ 連日 3 日間皮下交付後第 3 日の肝微細構造" は，すでに脂肪滴が多く，Ethionine の 作用の発現を早期から形態的に把握するには，交付後から脂肪発現に至る経過を時間的に観察する必要がある.

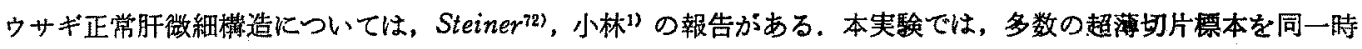
期に一度に作成するため，Glutaraldehyde による前固定を行ない， $\mathrm{O}_{8} \mathrm{O}_{4}$ 再固定後 Epoxy樹脂で包埋した，核 


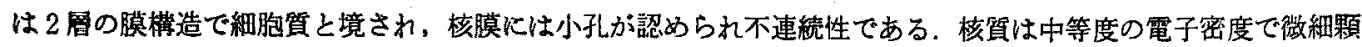
粒状棈造を呈し，電子密度の高いより大きな顆粒䄶造もみられ，1２個の核小体を有する. Mitochondria は 類円形, 桿状, ヒヨウタン型等の形状を呈し, ウサギに招いて Cristae mitochondrialesはヒト，ラット等に比

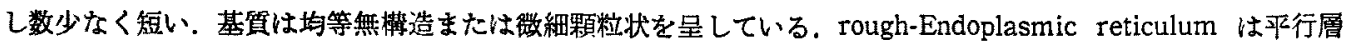
次配列を示し, Ribosome 顆粒が不均一拊着し, Poly-ribosome と思われる状態が観察された. smooth-Endoplasmic reticulum, Golgi complex 認められる. 肝細胞表面の Sinusoid は Microvilli が密生し. Endothelial cell および Kupffer 細胞化围まれて Disse 腔が存在する. Endothelial cell は不連続性である. Bile capillary は肝細胞相接部の限局性拻大部（内 $0.5 \sim 2 \mu$, 長さ $1 \sim 2 \mu$ ) として, Microvilli を有し，その两側に 細胞膜なよび絒胞質他かけ電子密度の高い tight junction (Desmosome) が認められる。

Ethionine $100 \mathrm{mg} / \mathrm{kg} 1$ 回交付後 $30 \mathrm{~m}$ で, Sinusoid の Microvilli 海造の変化が認められ, $1^{\mathrm{h}}$ で Mic-

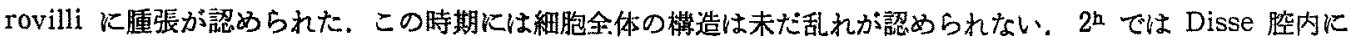

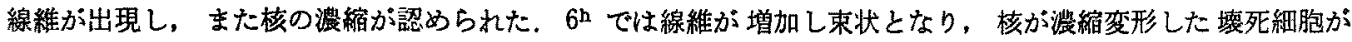
Sinusoid 周辺にみられ, Sinusoid の Microvilli の唻造は乱れ。短小化を来たす. rough-Endoplasmic reticulum の平行配列と Ribosome は未だ認められる。1 $12^{\text {h }}$ では Sinusoid 周辺の線維, 壊死細胞が認められ， rough-Endoplasmic reticulum は平行配列の分散短小化と表面の Ribosome の脱落傾向と脂肪滴の出現が認め られた. Disse 腔の閉塞は起こらず, Bile capillary がやや桩大し，その Microvilli の短小化が認められる. $24^{\mathrm{h}}$ では核小体がやや正常と橉造を異にし，細胞貿の空胞化の增加がみられ，Bile capillary は著しく桩大し， その Microvilli の檏造は著しく乱れ，脱落もみられた. 1列の rough-Endoplasmic reticulum が Mitochondria に沿らように位姐して認められる. 48 では Sinusoid 周辺の線維は Disse 堔に束状となってみら机。

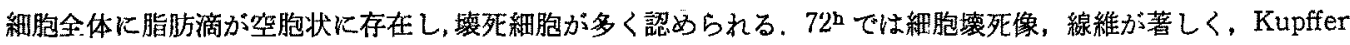
細胞が肥大してみられ，Disse 腔は正常に比し拆大して中に線維束が充満している部分も認められる．脂肪滴は 融合が起こってくる. Mitochondria はやや膨潤したものがみられるが，大体において著しい变化は認められな かった（写真 $1 \sim 8)$.

これらの初期変化の検索は，Ethionine $100 \mathrm{mg} / \mathrm{kg}$ 交付後第 3 日，すなわち $120^{\mathrm{h}}$ 以降の小林の報告1に につ ながり，100 $\mathrm{mg} / \mathrm{kg}$ 連日 3 日間皮下交付によって䈍起する中等度肝障害の成立について，第 1 回交付後 $30^{\mathrm{m}}$ か ら28日間に至る镜察が行なわれたことになる．Ethionine の肝障害は先す肝の蛋白代謝を障害することに始まる

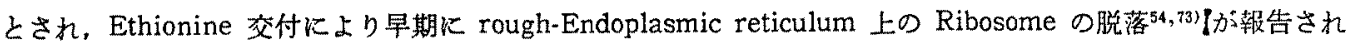
ているが，本実験では $6^{\text {h }}$ と捄いても rough-Endoplasmic reticulum の平行配列および Ribosome がみられ， $12^{\mathrm{h}}$ でその配列の分散短小化と Ribosome の脱落傾向を認め, $72^{\mathrm{h}}$ においても 1 列の rough-Endoplasmic

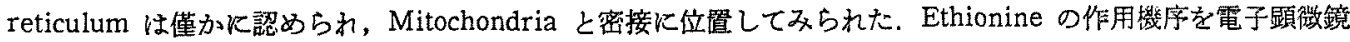
的検索の観点からみると，まず肝 Sinusoidの Microvilli を障害し，それによって血液との物質の交換の異常， 血中への醭素の逸脱が起こると考党られる。次いで Sinusoid门の Microvilli 周辺に線維が增生するが，慢性 Ethionine 障害時の 線維は胆毛紐管の(增殖が足場となる74) とされており，細胆管炎性胆汁性肝硬変の場合は Sinusoid 壁の Kupfferl縕胞, Endothelial cell が胆汁で慢性に刺激されて格子様線維の膠原化が起こるとい 5 ${ }^{75)}$. 本実験のごと急性実験による線維の出現は，薬物の投与中止によって消失すると考光られ，瑇物の侵入 に対する防御的な役割を果たするのと思われる。この線維が Ethionine の如何なる投与条件で，より增殖し不 可逆化するか，または Sinusoid 周辺に現われる線維は可逆性のもので，長期投与によって，Bile capillary に

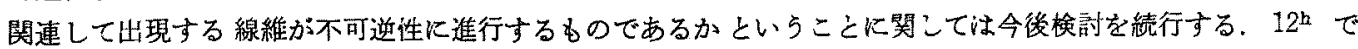
Ribosome の脱落がみられる時期に細胞内に脂肪滴が出現する. この脂肪滴の出現に関し, rough-Endoplasmic reticulum の障害がリポ蛋白の蛋白部分の産生を低下せしめ，それによって肝中性脂肪の血中への移動が㧕制さ

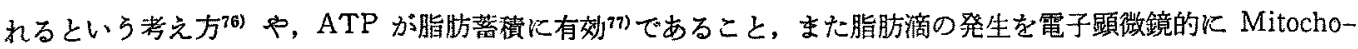
ndria, Endoplasmic reticulum 等を起源とする諸説もあり，Baglio ら ${ }^{55}$ は Ethionine 障害時には, Endopl一 asmic reticulum から形成されると示唆している。この詳細を明らかにするには，生化学的娭索や電子蹎徽鏡的 
ウサギ肝細胞徽細構造（超薄切片法， §）

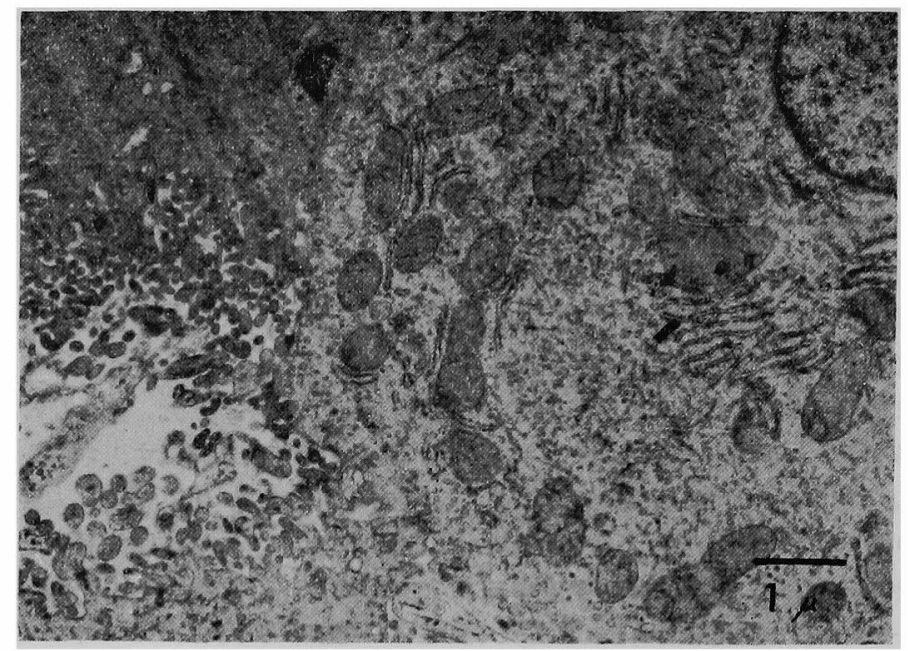

写真 1. Ethionine $100 \mathrm{mg} / \mathrm{kg}$ 皮下交付後 $30^{\mathrm{m}}$. $(\times 18,000)$

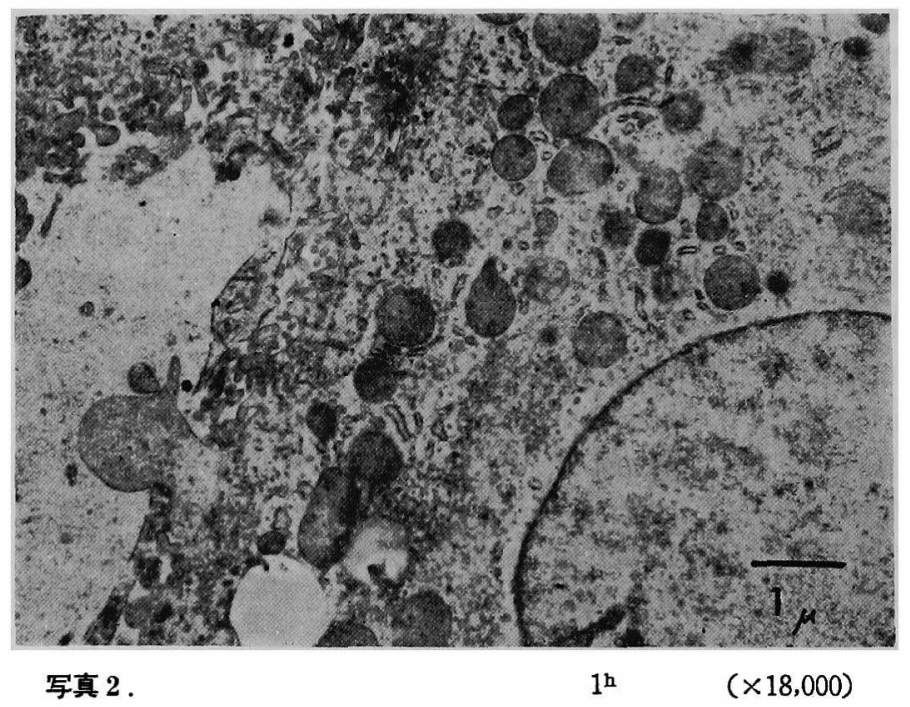




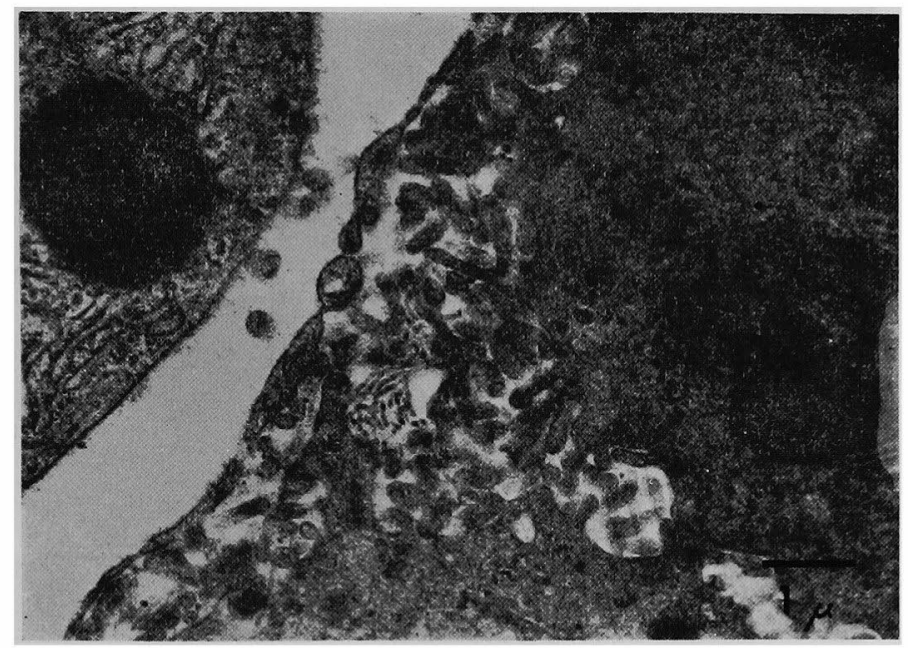

写真 3 . Ethionine $100 \mathrm{mg} / \mathrm{kg}$ 皮下交付後 $2^{\mathrm{h}}$.

$(\times 18,000)$

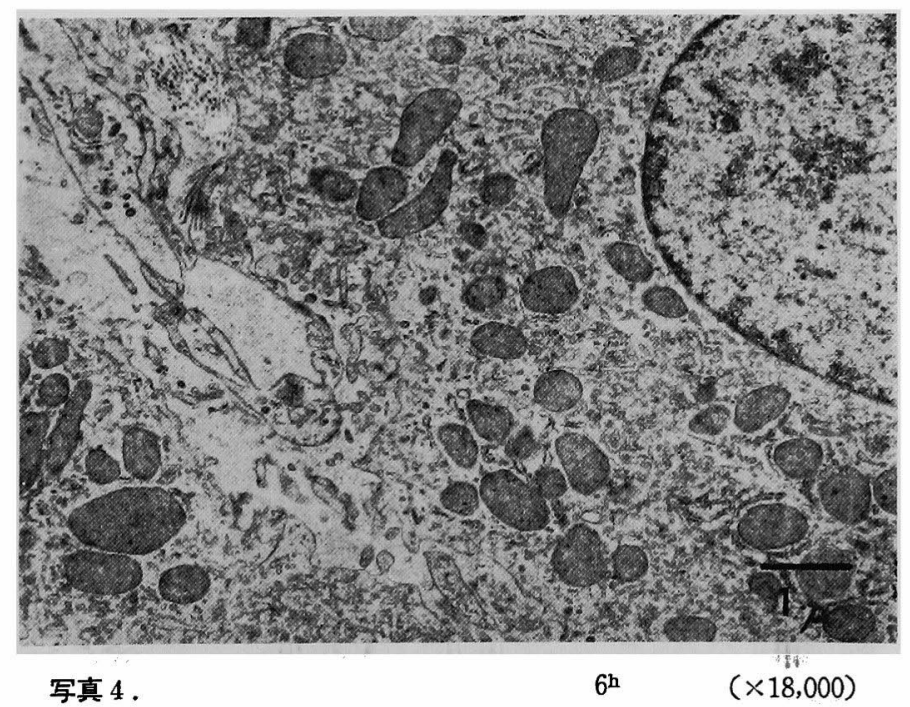




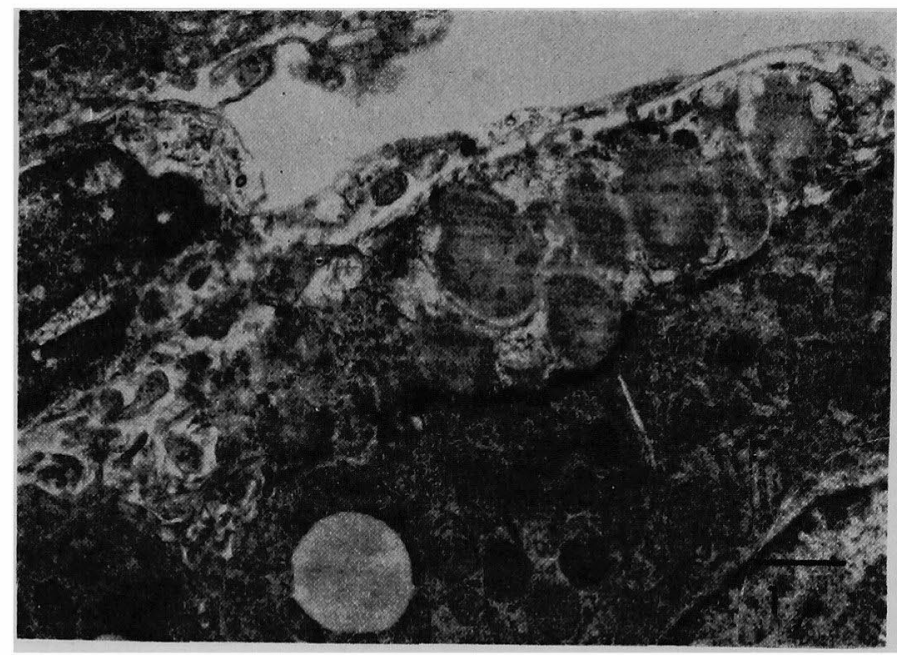

写真 5 . Ethionine $100 \mathrm{mg} / \mathrm{kg}$ 皮下交付後 $12^{\mathrm{h}}$.

$(x 18,000)$

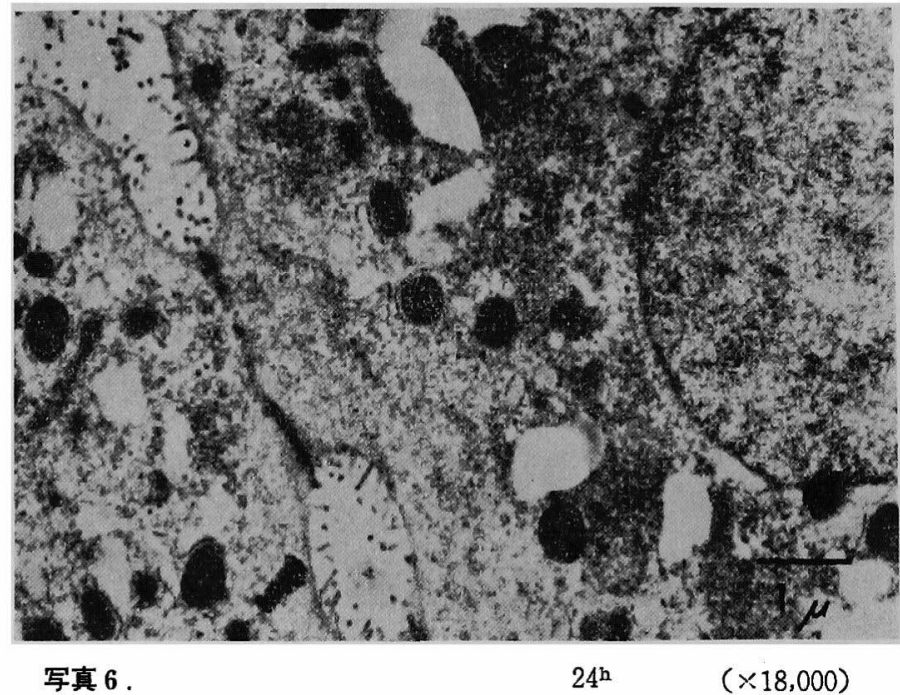




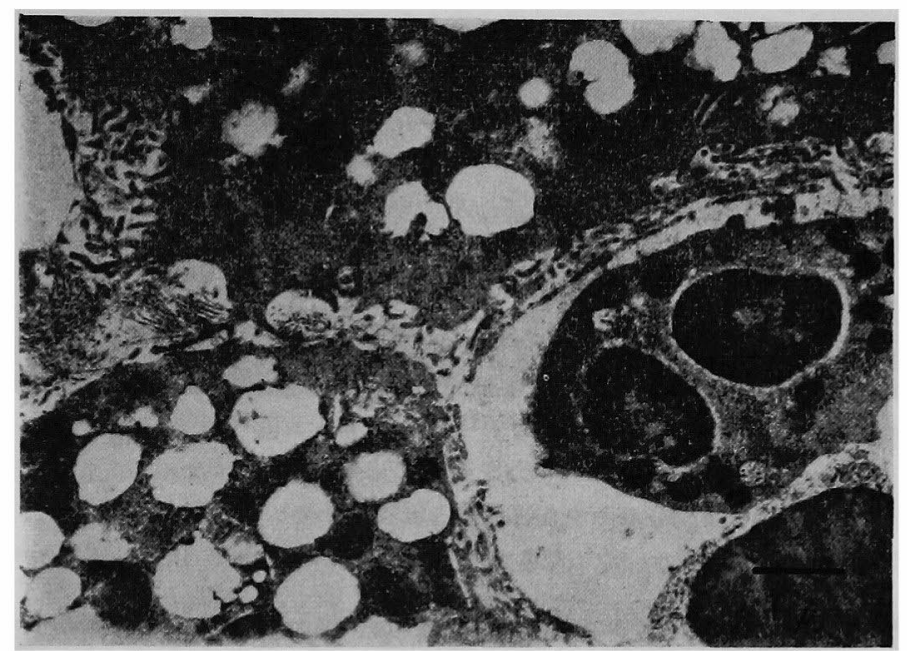

$(\times 18,000)$

写真 7. Ethionine $100 \mathrm{mg} / \mathrm{kg}$ 連日 2 日間皮下交付後 $24^{\mathrm{h}}\left(48^{\mathrm{h}}\right)$.

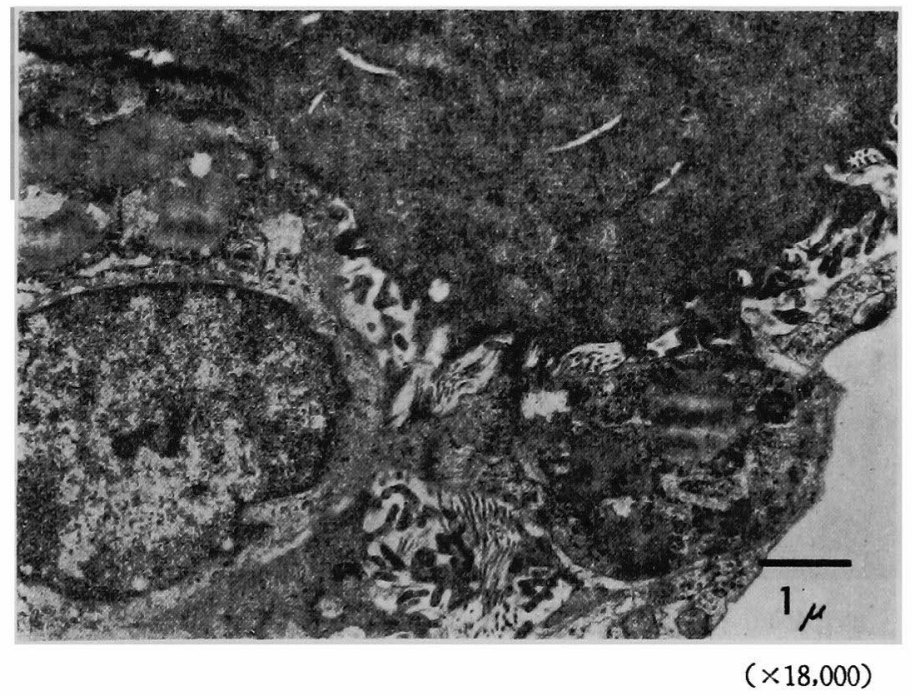

写真 8 . Ethionine $100 \mathrm{mg} / \mathrm{kg}$ 連日 3 日間皮下交付後 $24^{\mathrm{h}}\left(72^{\mathrm{h}}\right)$. 


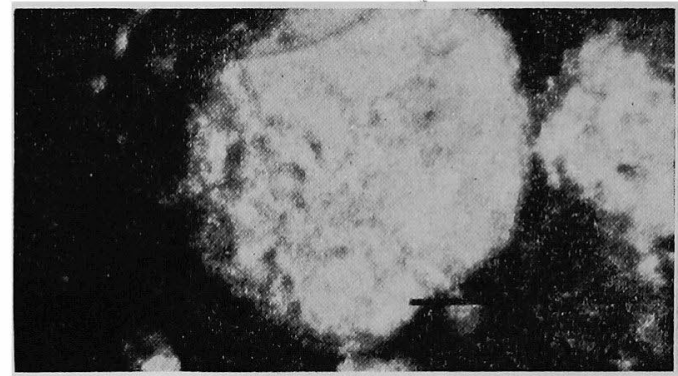

写真 9. a. 正常

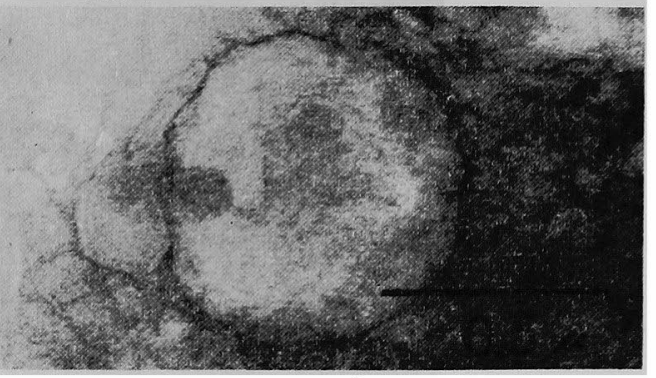

b. 正常

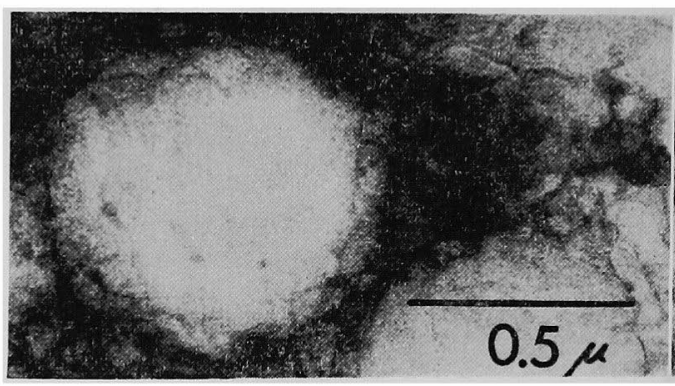

c. $12^{\mathrm{h}}$

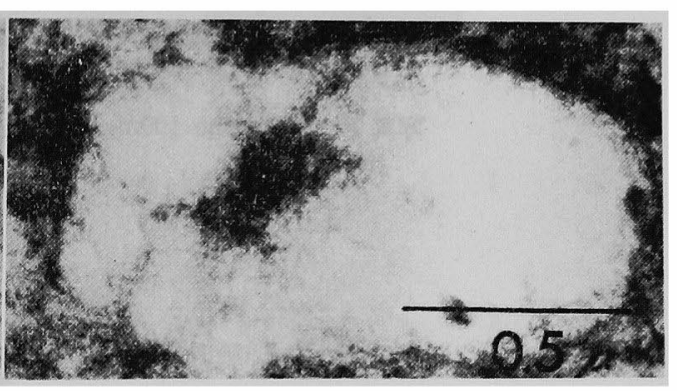

d. $24^{\mathrm{h}}$

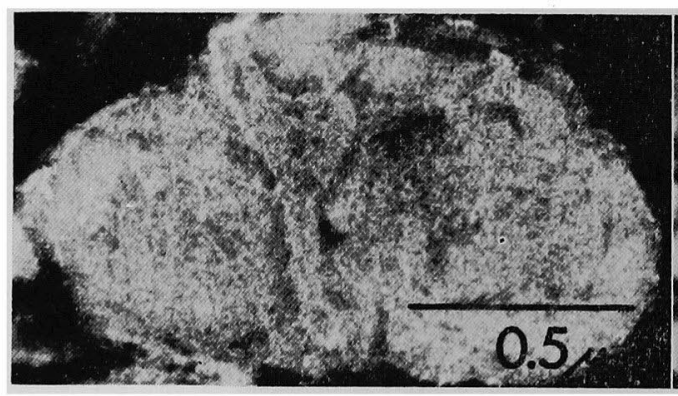

e. $48^{\mathrm{h}}$

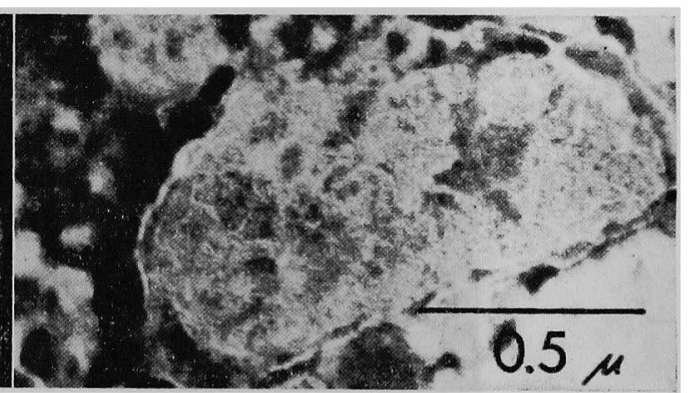

f. $72^{\mathrm{h}}$ 
radioautography を併用しての俭討が必要であると考光る。12 以降は脂肪滴，壊死細胞の出現等細胞棬造の破 壊が進み，従って細胞全体に3 次元的に網工をなす smooth-Endoplasmic reticulum の樓造変化が予想され， その代謝変動および細胞内物質輸送の缡害が起こると考えられる，Bile capillary の拡大は，細胞構造の変化が

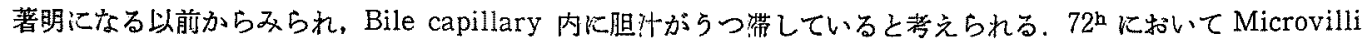
の減少した Disse 腥が Bile capillary に向かって桩大してくるような所見がみられているが，Disse 腔と Bile capillary を結ぶ肝細胞相接部に離開が生ずれば, 胆汁の Sinusoid への这流による黄疸の発生 ${ }^{78)}$ 子予想される. Ethionine 交付によるウサギの黄疸症状は， $100 \mathrm{mg} / \mathrm{kg}$ 連日 3 日間皮下交付後 3 日頃から，個体差恬あるが見ら

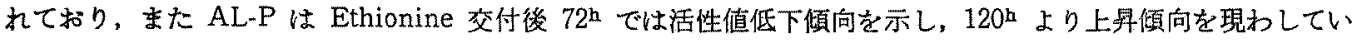
ることは前述した Desmosome の唯開による機能变化とも考えられる.

2) Negative 染色法による微䋱權造の観察

Mitochondria の構造変化と思われるるのは, Ethionine $100 \mathrm{mg} / \mathrm{kg}$ 交付後 $24^{\mathrm{h}}$ 以降において認められ，

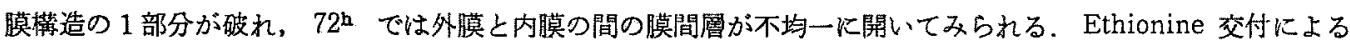
Mitochondria の変化は, $100 \mathrm{mg} / \mathrm{kg}$ 莗日 3 日間交付後 $24^{\mathrm{h}}$,すなわち $72^{\mathrm{h}}$ での電子顕微镜的観察によって僅か K膨潤がみられ，他の小器官飞比しその変化は遅れるものと推測される（写真 $9, a 〜 f)$.

Grisham ら ${ }^{79}$ は Ethionine 障害時 Mitochondria に著変がないと述べ，また脂肝には Mitochondria の 異常を伴わないるのもあるといわれている(2). Mitochondria の Negative 染色については, Fernãndez-Morā-

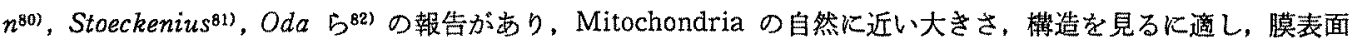
の粒子棈造等生物膜の分子レベルの钼察も可能とされている. Mitochondria の綪造変化には型化, 空胞化,

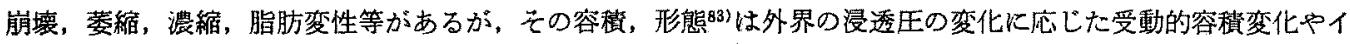

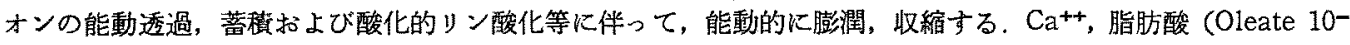
$\left.{ }^{6} \mathrm{M}\right)$, Glutathione $(0.01 \mathrm{M})$, 各種 Peptide hormone, Thyroxine $\left(10^{-5} \mathrm{M}\right)$. Cysteine $(0.01 \mathrm{M})$ では膨潤がみ られている.

本実験で Ethionine 交付後に Negative 染色によって観察された Mitochondriaは，その噴䂛濃度がやや 濃く, seat mesh の Collodione 膜が少し厚かったため 3 万倍の観察にとどめた，膜間層の離開は正常ではみら れず，病的状態による機能変化により，間琶に水が入って開くとも考克られており，分離 Mitochondria では開 いていることが多いとされるが，今後 micro grid 法の導入により，正常像との比較を充分に行ない, Mitochondria の変化を基本的模棈造の面より検钨してゆく予定である.

\section{IV 䋓括ならびに考察}

以上の Ethionine による肝障害成立機序に関する構造と機能面からの実験結果を次のごとく総括し，考察 する.

1. 蛋白，脂質代謝面の実験において，倠蜼ウサギに対し $30 \mathrm{mg} / \mathrm{kg}, 100 \mathrm{mg} / \mathrm{kg}$ 連日 3 日間 皮下交付で は，交付後 1，3，7 日にいずれも血清 Albumin の減少による A/G 比の減少， $\beta$-リポ蛋白の增加と血清総 Cholesterol の增加を来たし，ラットにおいて報告されているような著しい性差は認められなかった。

2. 精質代謝面の実験に执いて，始性ウサギに対し血煻は Ethionine $100 \mathrm{mg} / \mathrm{kg} 1$ 回交付後 $2^{\mathrm{h}}$ 迄は一過 性の上界を来たすが，以後は逐時的に減少傾向を示し，連日 3 回交付後 7 日，すなわち第10日に至り回復傾向を 現わすことを認めた，これは Ethionine による肝障害の成立とその自然治澺傾向とに時日の経過に和いてほほ 一致している.

3. 血清酵素代謝の実験において，血清 GOT，GPT 活性值は当初著明な変動を来たさず，Ethionine 3

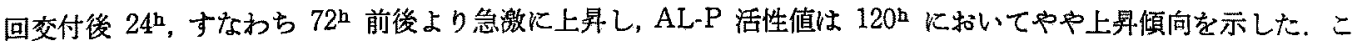
わらの障害に基つく活性値上我は, 自然治瘜傾向のみられる第10日前後にはほぼ回復することが認められた。れ に対し肝細胞上清分画の GOT は，Ethionine $100 \mathrm{mg} / \mathrm{kg}$ 第 1 回交付後 $12^{\mathrm{h}}$ から活性值が低下することを認め，

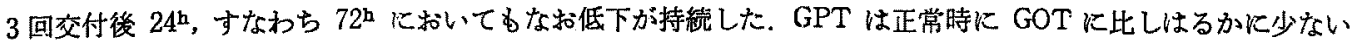


活性を示した，障害時にはややばらつきを生したが、汪ぼ GOT と一致した活性值低下傾向を認めたすななわち 血清と肝上清分画との間に括いて Transaminase 活性変化は逆相関を示し, 上清分画では交付後 $12^{\mathrm{h}}$ 以降に細胞 実質の障害に基つ゚くと考えられる活性低下が認められ，これに対し血清ではやや遈れるが，Ethionine $100 \mathrm{mg} / \mathrm{kg}$ 交付 $72^{\mathrm{h}}$ 前後より活珄上界が出現し, 細胞内酥素の血中逸脱傾向が認められた。

4. 肝 rough-Endoplasmic reticulum と甜ける Ethionine の蛋白代謝阻宫作用の実験として，57,000× g

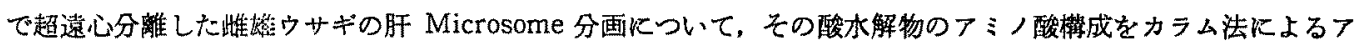
ミノ酸分析機で測定し，アミノ酸棬成の比率は崔雄共に同一傾向であることを認め, 湘定に際し Ethionine の patternはその Leucine 分画に一致して出現しままたthionine 交付により粠成比率に変化が現われることを 認めた，次いで Bioassay の併用により，Ethionine 障密の極期前後には Microsome 分画中に Ethionine たは Ethionine 含有異常蛋白が存在することを認めた。この結果は Ethionine の作用機序が rough-Endoplasmic reticulum における蛋白合成阻富にあり，S-adenosyl-ethionine の出現が異常蛋白の生成をるたらすとい ら他の研究者らの報告とも一致し，Ethionine による肝疾患模型病像の成立機序の解明に対し，一つの証明とし て重要な手がかりを示するのと思考される。

5. 肝細胞微細楎造の電子顕微鏡的観察において, 超薄切片法では Ethionine $100 \mathrm{mg} / \mathrm{kg}$ 第 1 回交付後 $30^{\mathrm{m}}, 1^{\mathrm{h}}$ K Sinusoid の Microvilli の漛造変化が, $2^{\mathrm{h}}$ で Sinusoid 周辺の内皮基底膜飞 bleb (腫張) が起こ り，またその周辺の一部に線維が出現し，6占ではさらに線維が増加して束状を呈することが認められた．この

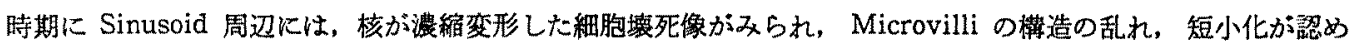
られた。 $12^{\mathrm{h}} て ゙$ rough-Endoplasmic reticulum の平行配列の分散短小化と，その表面の Ribosome の脱落が みられ，脂肪滴の出現と Bile capillary の拡大およびその Microvilli の短小離開化が認められた. $24^{\mathrm{h}}$ では 核小体にやゃ変化がみられ，Bile capillary は著しく拻大しその Microvilli の脱落が起こり，rough-Endoplasmic reticulum は1列となり，Mitochondria に沿った位置に僅が存在した４ $48^{\mathrm{h}}$ では脂肪滴が細胞全体に脂 肪空胞状にみられ，Sinusoid 周辺に壤死細胞が多くみられた， $72^{\mathrm{h}}$ では脂肪滴の融合が起こり，Kupffer 細胞の 肥大がみられ，Disse 腔は拻大しその内部を線維束が占めている所見すみられた．Mitochondria にはこの時期 迄には著しい变化は認められなかった。この Mitochondria については，超薄切片法と平行して Negative 染 色を行ない，1個の Mitochondria 単位で観察したが，24h 以降において膜構造の変化，すなかち膜間層の不 均一な離開定認め, 膨㵎化傾向がうかがかれた。

以上の諸点上り考察すると，肝の障害に対する微紲楼造の変化は，比較的単純で種々の要因に対し極めて類 似した形態的変化を示しこれをすって直ちに機能変化と密接に関連つけて説明することはむずかしい，現在の

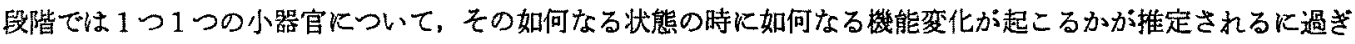
ない、しかしながら，Ethionine による肝障憲成立にあたり、これらの構造の変化を機能変化と相関させ，その 阿者接合点に括いて把握寸ることは，1つの実呀的肝疾患模型病像の基喏的検討飞貢献し，肝臓用薬の作用解明 に重要な手がかりとなしらるすのと思考する.

\section{$\mathrm{V}$ 結 論}

以上の実験結果を次のごとく要約し結論する。

1. Ethionine はウサギに和いては蛋白, 脂質代謝に対し，血清蛋白、リホ⿺蛋白，血消総 Cholesterol の 椧索により，倠雄つ間炕著しい性差を現わさない。

2. Ethionine はウサギつ糖質代謝に影響を扰よ注し，また障害つ進行につれ血清 Transaminase を增加 させる．これに刘し肝上清分画つTransaminase は逆相関を示し減少する.

3. ウサ半肝 Microsome 分画酸水解物つアミノ酸櫣成は，雌婎に推いて個々つ含量に若干つ差巽を認め るが比率つ上では同一傾向を示す，Ethionine によりてミノ酸棰成比は変動し，また Bioassay によりその Leucine 分画中に Ethionine 刀存在が認められる.

4. Ethionine はウサギにおいて極めて早期より肝細胞微細樹造の変化を起こさせ、特に Sinusoid 周辺 
に著明な影響を括よぼす. rough-Endoplasmic reticulum の分散, 短小化と，そつ Ribosome つ脱落は Ethi一 onine 交付後 $12^{\mathbf{h}}$ で著明となる. Mitochondria つ構造は，超薄切片法，Negative 染色とを併せ検索すると， Ethionine 交付後 $48 \sim 72^{\mathrm{h}}$ に膜つ湟潤化傾向を現わすことが認められる.

本馀文の要旨は日本薬理学会第38回総会および第34回関東部会において 発表したものである.

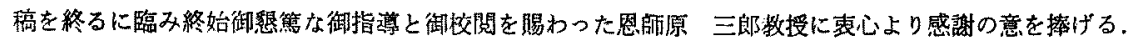

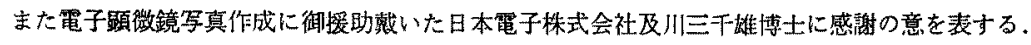

$$
\text { 文献 }
$$

1) 小林立德：日薬理壳, 62,333 (1966).

2）笠原多嘉子：日薬理誌揭載予定.

3) Farber, E., Koch-Weser, D. \& Popper, H. : Endocrinology, 48, 205 (1950).

4) 小林忠之: 薬学雑誌, 80, 1448 (1960).

5) Farber, E. \& Segaloff, A. : J. Biol. Chem., 216, 471 (1955).

6) 荒川辰彦: 医学研究, 27, 1141 (1957).

7) 吉永徹夫, 中野牧史，岩崎礼三：日消誌，53，12（1956）,

8）木谷威夫, 長岡 央, 酒茾幸男, 山本 毅, 中野牧史：同上誌，53，12（1956).

9) Edlund, Y. : Acta Path. Microbiol. Scand., 54, 173 (1962).

10) Wang, C., Porovetto, F., Sohar, E. \& Adlersberg, D. : A. M. A. Arch. Path., 65, 279 (1958).

11) 電気泳動研究会標準操作法小菖員会：生物物理化学，4，62（1958）.

12) Zak, B. : Am. J. Clin. Path., 27, 583 (1957).

13) Somogyi, M. \& Nelson, N. : J. Biol. Chem., 195, 19 (1952).

14) Kind, P. R. N. \& King, E. J. : J. Clin. Path., 7, 322 (1954).

15) Reitman, S. \& Frankel, S. : Am. J. Clin. Path., 28, 56 (1957).

16) Paigen, K. : Biochim. Biophys. Acta, 19, 297 (1956).

17）金茾 泉：臨床娭查法提要, VII30, 金原出版株式会社 (1966).

18) Spackman, D. H., Stein, W. H. \& Moore, S. : Anal. Chem., 30, 1190 (1958).

19）小原正美：Amino Acids · 発醇と代謝, 2, 142 (1960).

20）赤堀四郎, 水岛三一郎編：蛋白質化学，P.282, 共立出版株式会社 (1954).

21) Millonig, G. : Elec. Microscopy, Fifth Internat. congr. for Elec. Mic., II, p. 8, Academic Press (1962).

22) Luft J. H. : J. Biophys. Biochem. Cytol., 9, 409 (1961).

23) Brenner, S. \& Horne, R. W. : Biochim. Biophys. Acta, 34, 103 (1959).

24) Pool, J. G. \& Spaet, T. H. : Proc. Soc. Exptl. Biol. Med., 87, 54 (1954).

25) Hutterer, F., Rubin, E., Singer, E. J. \& Popper, H. : Cancer Res., 21, 205 (1961).

26) Paoletti, C., Riou, G. \& Truhaut, R. : Nature, 193, 734 (1962).

27) 近藤 得, 中川路 (坂本) 浩二 : 東医大誌, 16, 467 (1958).

28) Rice, C. E., Boulanger, P., Plummer, P. J. G. \& Annau, E. : J. Immunol., 68, 673 (1952).

29) Alvizouli, M. \& Cortes, J. : A. M. A. Arch. Path., 65, 279 (1958).

30) White, L. P. \& Shimkin, M. B. : Cancer, 7, 867 (1954).

31) Karvinen, E. \& Miettinen, M. : Acta Physiol. Scand., 56, 157 (1962).

32) Bezman-Tarcher, A., Nestel, P. J. \& Felts, J. M. : J. Lipid Res., 7, 248 (1966).

33) Furman, R. H., Norcia, L. N., Robinson, C. W. \& Gonzales, I. E. : Am. J., Physiol., 191, 561 (1957).

34) Harris, P. M. \& Robinson, D. S. : Biochem. J., 80, 352 (1961).

35）青山進午，菊地三郎，早川昌昭，田中義保，岡田朝生，伊藤 円：日消誌，57，934（1960).

36) Feinberg, H., Rubin, L., Hill, R., Entenman, C. \& Chaikoff, I. L. : Science, 120, 317 (1954). 
37) Lupu, C. I. \& Farber, E. :Proc. Soc. Expt1. Biol. Med., 86, 701 (1954).

38) Farber, E. \& Popper, H. : ibid., 74, 838, (1950).

39) Wang, C., Parovetto, F., Sohar, E. \& Adlersberg, D. : A. M. A. Arch. Path., 65, 286 (1958).

40) 高橋忠雄, 小田正幸, 内藤聖二：臨床消化器病学, 2, 480 (1954).

41) Segal, H. L. \& Washko, M. E. : J. Biol. Chem., 234, 1937 (1960).

42）高橋忠雄監修：肝臓一構造，機能，蹦床， P.131，P. 576, 医学書院 (1964).

43）福井 晃, 朝田 誠, 杉本公吉, 河田 鍳：日消誌，53，575 (1956).

44）古川一彦, 西喜代治, 豊岛芳貞, 左座 寞：肝臓, 2, 191 (1961).

45) Roberts, W. M. : Brit. J. Exp. Med., 11, 90 (1930).

46) de Duve, C. et al.: Advances in Enzymology, vol. 24, p. 291,Inter Science Pab., New York (1962).

47) Schneider, W. C. \& Hodgeboom, G. H. : J. Biol. Chem., 183, 123 (1953).

48) Farber, E. \& Corban, M. S. : ibid., 233, 625 (1958).

49) Villa-Trevino, S., Shull, K. H. \& Farber, E. : ibid., 238, 1757 (1963).

50) Levine, M. \& Tarver, H. : ibid., 192, 835 (1951).

51) Rabinovitz, M., Olson, M. E. \& Greenberg, D. M. : ibid.,227, 217 (1957).

52) Gross, D. \& Tarver, H. : ibid., 217, 169 (1955).

53) Yoshida, A. : Biochim, Biophys, Acta, 29, 213 (1958).

54) Arakawa, K. : J. Electronmicroscopy, 8, 54 (1960).

55) Baglio, C. \& Farber, E. : Fed. Proc., 24, 556 (1965).

56) Eber, L., Fitzgerald, P. J. \& Herman, L. : ibid., 21, 303 (1962).

57) Claude, A. : "Harvey Lectures", vol. XLIII, p. 121 (1947 1948).

58) Chauveau, J., Rouiller, C. \& Schneebeli, J. : J. Cell Biol., 12, 17 (1962).

59) Baran, A. \& Bartley, W. : Biochem. J., 79, 159 (1961).

60) Spiro, M. J. \& Mckibbin, J. M. : J. Biol. Chem., 219, 643 (1956).

61) Simkin, J. L.\& Work, T. S. :Biochem. J., 67, 617 (1957),

62) 中原和郎, 藤井 隆, 三浦義榇螎：細胞生物学, P.180, 朝倉書店 (1967).

63) $T s^{\prime} O$, P. O. P., Bonner, J. \& Dintzis, H. : Arch. Biochem. Biophys., 76, 225 (1958).

64) Champton, C. F. \& Petermann, M. L. : J. Biol. Chem., 234, 2642 (1959).

65) Bulter, J. A. V. \& Simson, P. : Biochim. Biophys. Acta, 38, 386 (1960).

66) Palade, G. E. \& Siekevitz, P. : J. Biophys. Biochem. Cytol., 2, 171 (1956).

67) Moulé, Y., Rouiller, C. \& Chauveau, J. : ibid., 7, 547 (1960).

68) Fouts, J. R. : Biochem. Biophys. Research Comm., 6, 373 (1961).

69) Moore, S. \& Stein, W. H. : Methods in Enzymology, 6, 819 (1963).

70) 箸本漓珄吉: 生体の科学, 15, 114 (1964).

71) 山村雄一, 勝沼信彦, 藤井節郎 : 臨床醭素学必携, p.360, 南山堂 (1966).

72) Steiner, J. W. : Pathology, 38, 411 (1961).

73）和田昌也：名古屋市立大医誌，14，251（1964）.

74) Popper, H., Schaffner, F. \& Hutterer, F. : Ann. N. Y. Acad. Sci., 86, 1075 (1960).

75) 志方俊夫：総合臨休, 8, 1857 (1959).

76) Heimberg, M., Weinstein, I., Dishmon, G. \& Dunkerley, A. : J. Biol. Chem., 237, 3623 (1962).

77) Farber, E., Lombardi, B. \& Castillo, A, E. : Lab. Invest., 12, 873 (1963).

78) Cossel, L. : Münn. Med. Wschur., 107, 1376 (1965).

79) Grisham, J. W. et al. : Am. J. Med., 30, 157 (1961).

80) Fernãndez-Morän, H. : Circulation, 26, 1039 (1962).

81) Stoeckenius, W. : J. Cell Biology, 17443 (1963).

82) Oda, T. \& Nishi, Y. : J. Electronmicroscopy, 12, 290 (1963).

83) Lehninger, A. L. : “The Mitochondria”, Academic Press (1964). 